\title{
Synthesis and Properties of 6'-Fluoro-tricyclo-DNA
}

\author{
Michal Medvecky, Alena Istrate and Christian J. Leumann* \\ Department of Chemistry and Biochemistry, University of Bern, Freiestrasse 3, CH-3012 Bern, \\ Switzerland
}

* Email: christian.leumann@dcb.unibe.ch 


\title{
Table of Contents graphic:
}

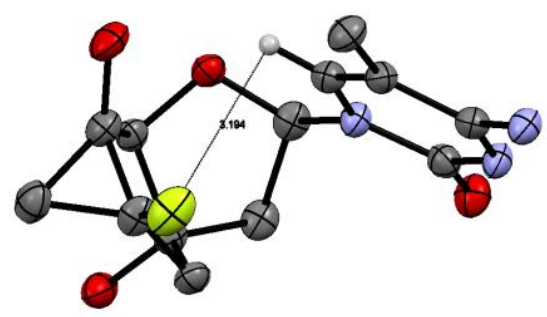

\begin{abstract}
The synthesis of the two fluorinated tricyclic nucleosides 6' F-tc-T and 6' F-tc-5 ${ }^{\mathrm{Me}} \mathrm{C}$, as well as the corresponding building blocks for oligonucleotide assembly was accomplished. An X-ray analysis of $\mathrm{N}^{4}$-benzoylated 6'F-tc- ${ }^{5 \mathrm{Me}} \mathrm{C}$ reavealed a 2'-exo (North) conformation of the furanose ring characterizing it as an RNA mimic. In contrast to observations in the bicyclo-DNA series, no short contact between the fluorine atom and the H6 of the base, reminiscent of a non-classical $\mathrm{F}^{\cdots} \mathrm{H}$ hydrogen bond, could be observed. $T_{\mathrm{m}}$ measurements of modified oligodeoxynucleotides with complementary RNA showed slightly sequence dependent duplex stabilization profiles with maximum $\Delta T_{\mathrm{m}} / \mathrm{mod}$ values of $+4.5^{\circ} \mathrm{C}$ for $6^{\prime} \mathrm{F}-\mathrm{tc}-{ }^{5 \mathrm{Me}} \mathrm{C}$ and $+1^{\circ} \mathrm{C}$ for $6^{\prime} \mathrm{F}$-tc- $\mathrm{T}$. In comparison with parent tc-modified oligonucleotides, no relevant changes in $T_{\mathrm{m}}$ were detected, attributing the fluorine substituent a neutral role in RNA affinity. A structural analysis of duplexes with DNA and RNA by CD-spectroscopy revealed a shift from B- to A-type conformation induced by the 6'F-tc-nucleosides. This is not a specific 'fluorine effect' as the same is also observed for the parent tc-modifications. The two fluorinated tc-nucleosides were also incorporated into a pure tricyclo-DNA backbone and showed no discrimination in $T_{\mathrm{m}}$ with complementary RNA, demonstrating that 6'F substitution is also compatible within fully modified tc-oligonucleotides.
\end{abstract}




\section{Introduction}

Fluorine is widely appreciated in small molecule medicinal chemistry due its metabolic stability enhancing properties and its unique protein binding characteristics. ${ }^{1-3}$ For similar reasons fluorinated DNA analogues are of interest in oligonucleotide therapeutic approaches. Amongst the first fluorinated oligonucleotides investigated were the 2'-deoxy-2'-fluoro RNA (F-RNA) and the 2'deoxy-2'-fluoro-arabino nucleic acids (F-ANA, Figure 1). While both analogues are known for quite some time, their structural and biophysical features have only recently been characterized in detail. Compared to their 2'-hydroxy variants RNA and ANA, both the F-RNA and F-ANA analogues bind with higher affinity $\left(\Delta T_{\mathrm{m}}=1-2^{\circ} \mathrm{C} / \mathrm{mod}\right)$ to complementary RNA. The origin of the higher duplex stability in the case of F-RNA was attributed to improved hydrogenbonding and base-stacking as a consequence of the polar C2'-F bond. ${ }^{4,5}$ In the case of F-ANA, internucleoside F-H8 pseudo hydrogen-bonds, that are particularly strong at purine/pyrimidine sequence steps, have been invoked as stability enhancing feature. ${ }^{6,7}$ F-RNA and F-ANA have been shown to improve the performance of therapeutic siRNAs. ${ }^{8,9}$ Due to its unique RNaseH activating properties, F-ANA was also investigated in classical antisense applications. ${ }^{10}$

Recently there has been a growing interest in investigating the effect of fluorine substitution in more complex, carbohydrate modified oligonucleotide analogs such as F-HNA and its 2'-epimer Ara-F-HNA. ${ }^{11,12}$ While F-HNA shows increased thermal stability $\left(\Delta T_{\mathrm{m}}=+2{ }^{\circ} \mathrm{C} / \mathrm{mod}\right)$ in complex with complementary RNA, the F-Ara-HNA analogue exhibits the opposite effect $\left(\Delta T_{\mathrm{m}}=-3\right.$ $\left.{ }^{\circ} \mathrm{C} / \mathrm{mod}\right)$. The destabilization of Ara-F-HNA was attributed to repulsive steric effects of the

fluoro substituent onto the $5^{\text {' }}$-adjacent nucleotide unit. ${ }^{11}$ Also fluorinated versions of $\mathrm{CeNA}^{13}$ and cLNA $^{14}$ were investigated. In these cases fluorine substitution does not contribute significantly to duplex stability. The most recent additions to the palette of fluorinated oligonucleotide analogues 
were F-NMC and Ara-F-NMC, ${ }^{15}$ both derived from the northern methanocarbacyclic nucleoside (NMC) analogues. ${ }^{16,17}$ Here again, F-NMC stabilized duplexes by $+2.2^{\circ} \mathrm{C} / \mathrm{mod}$ on average while Ara-F-NMC was destabilizing by $-2.8^{\circ} \mathrm{C} / \mathrm{mod}$. The intrinsic contribution of the fluorine atom to thermal stability in the case of F-NMC was determined to be $+0.6^{\circ} \mathrm{C} / \mathrm{mod}$ on average. ${ }^{18}$

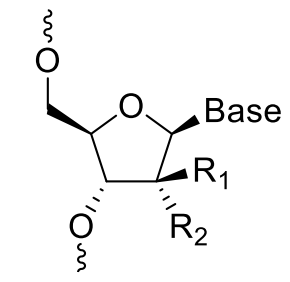

$\mathrm{R}_{1}=\mathrm{H}, \mathrm{R}_{2}=\mathrm{F}: \mathrm{F}-\mathrm{RNA}$ $\mathrm{R}_{1}=\mathrm{F}, \mathrm{R}_{2}=\mathrm{H}: \mathrm{F}-\mathrm{ANA}$

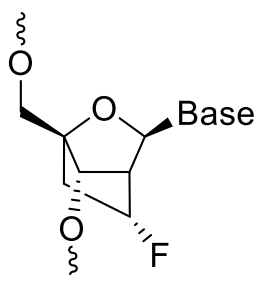

$(R) \mathrm{F}$-cLNA

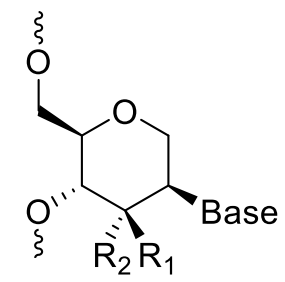

$\mathrm{R}_{1}=\mathrm{H}, \mathrm{R}_{2}=\mathrm{F}: \mathrm{F}-\mathrm{HNA}$ $\mathrm{R}_{1}=\mathrm{F}, \mathrm{R}_{2}=\mathrm{H}$, Ara-F-HNA

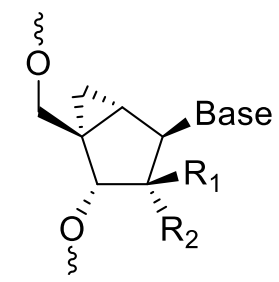

$\mathrm{R}_{1}=\mathrm{H}, \mathrm{R}_{2}=\mathrm{F}: \mathrm{F}-\mathrm{NMC}$ $\mathrm{R}_{1}=\mathrm{F}, \mathrm{R}_{2}=\mathrm{H}$, Ara-F-NMC

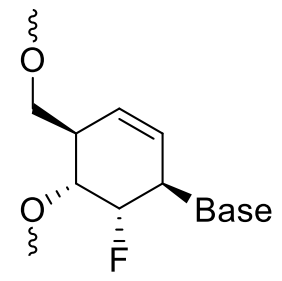

F-CeNA

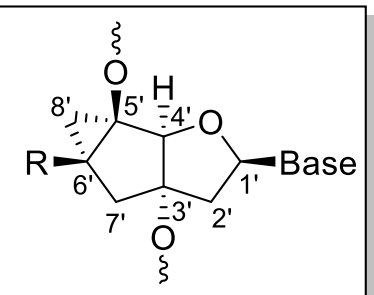

$\mathrm{R}=\mathrm{H}$, tc-DNA $\mathrm{R}=\mathrm{F}, 6^{\prime}$ F-tc-DNA

FIGURE 1: Chemical Structures of selected fluorinated nucleic acid analogues

In terms of biological activity it has been shown previously that F-HNA gapmers can downregulate gene expression in vivo in liver tissue more potently than LNA despite lower target affinity. ${ }^{11}$ Thus, the higher potency of F-HNA seems to be the consequence of either improved biostability or more efficient plasma transport or both. Other recent observations, attributing a special but yet elusive role to fluorine in antisense efficacy were reported for gapmer oligonucleotides with F-RNA or F-ANA units targeting mutant huntingtin, ${ }^{19}$ and for F-RNA antisense oligonucleotides recruiting the interleukin enhancer-binding factor complex (ILF2/3). ${ }^{20}$ 
Given these intriguing properties of fluorinated oligonucleotides, and building on earlier work on 6'F-bicyclo-DNA, ${ }^{21}$ we decided to investigate 6'F-tc-DNA (Figure 1). In the following we present the synthesis and structural properties of the corresponding 6'F-tc-nucleosides containing the bases thymine and 5-methyl cytosine, as well as the influence on duplex stability and conformation of these modifications if complexed with complementary RNA and DNA.

\section{Results and Discussion}

Synthesis of the phosphoramidite building blocks 11 and 18. Drawing on earlier experiences during the synthesis of 6'-fluorinated bicyclo-DNA ${ }^{21}$ we envisaged to introduce the fluorine atom in an early step of the synthesis via electrophilic fluorination of a metalated bicyclic sugar intermediate. Consequently we started our synthetic journey with the known bicyclic silylenol ether $\mathbf{1}$ (Scheme 1). ${ }^{22}$ Bromination of $\mathbf{1}$ with $\mathrm{Br}_{2}$ at $-78^{\circ} \mathrm{C}$ gave the expected bromide $\mathbf{2}$ in $90 \%$ yield. To exclude side reactions during the following metal-halogen exchange, the free $\mathrm{OH}$ group in $\mathbf{2}$ was protected as a TMS ether $(\rightarrow \mathbf{3})$. Electrophilic fluorination of $\mathbf{3}$ worked best if $\mathrm{t}-\mathrm{BuLi}$ was used as lithiation reagent and if NFSI was added in one portion at a temperature of $-120{ }^{\circ} \mathrm{C}$. Temperatures above $-78^{\circ} \mathrm{C}$, or addition of NFSI in multiple portions, lead to substantial decomposition and thus reduced yield. The treatment with an acidic ion exchange resin after quenching of the reaction quantitatively removed the TMS group, resulting in a $60 \%$ yield of fluorosilylenol ether 4. The rationale of removing the TMS group at this stage was based on the hypothesis that the corresponding hydroxyl group could help in directing the subsequent cyclopropanation reaction to the convex side of the bicyclic ring system. Indeed, cyclopropanation of $\mathbf{4}$ with a $\mathrm{Zn}$-carbene complex in homogeneous solution yielded exclusively

the exo-tricyclic sugar $\mathbf{5}$ in good yield, but only if TFA was added as accelerator. ${ }^{23}$ To prepare for 
$\beta$-selective nucleosidation, ${ }^{24,25}$ compound 5 was converted to enolether $\mathbf{6}$ with TMSOTf, which was then reacted with in situ persilylated thymine and NIS, yielding iodo-nucleoside 7 in $85 \%$ yield in a stereospecific manner. Removal of the iodine via radical reduction with $\mathrm{Bu}_{3} \mathrm{SnH}$ finally gave the expected O-protected 6'-fluoro tricyclothymidine $\mathbf{8}$ in excellent yields. From here the synthesis of the phosphoramidite building block was completed by standard removal of the silyl protecting groups $(\rightarrow \mathbf{9})$ followed by dimethoxytritylation $(\rightarrow \mathbf{1 0})$ and phosphitylation with 2 cyanoethyl diisopropyamino chlorophosphine $(\mathrm{CEP}-\mathrm{Cl})$ to give $\mathbf{1 1}$ in a respectable overall yield of $13.4 \%$ starting from $\mathbf{1}$.

\section{SCHEME 1. Synthesis of phosphoramidite 11}

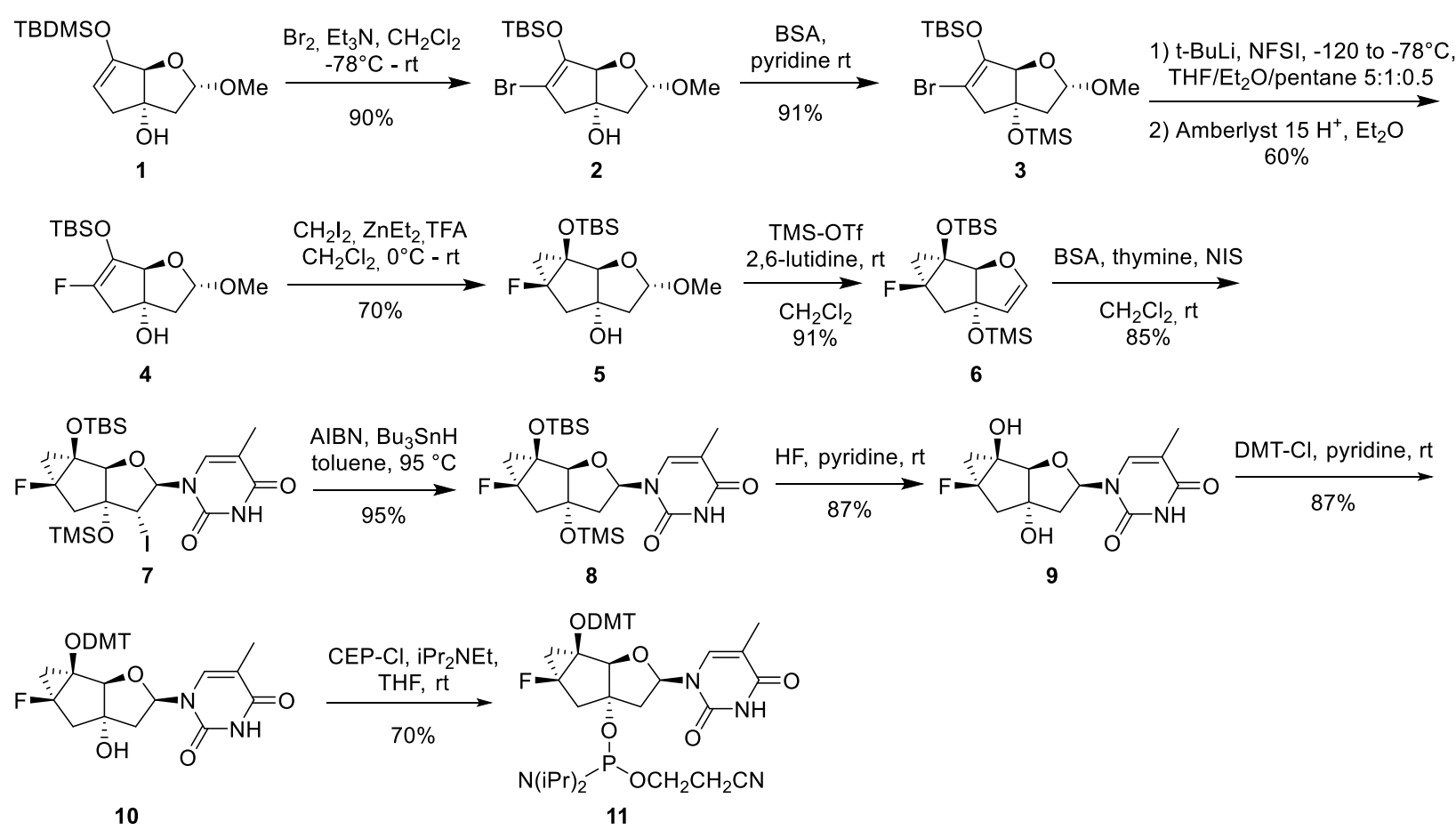

Given the availability of the thymine nucleoside $\mathbf{8}$ and known procedures to interconvert pyrimidine bases on the level of nucleosides and oligonucleotides, ${ }^{26,27}$ we next envisioned the synthesis of the building block 18 containing the base 5-methyl cytosine. To this end compound $\mathbf{8}$ 
was transformed into the triazolide 12 with 1,2,4-triazole and $\mathrm{POCl}_{3}$. Treatment of $\mathbf{1 2}$ with ammonia then afforded the 5-methly tricyclocytidine $\mathbf{1 3}$ in $60 \%$ yield over two steps. $\mathrm{N}^{4}$ Benzoylation of 13 with $\mathrm{Bz}_{2} \mathrm{O}$ yielded the two nucleosides 14 and $\mathbf{1 5}$ that differed only by the presence or absence of the 3'-O-TMS group. This was of no harm as the silyl groups in both, 14 and 15 were removed in the next step, yielding 16 in high yield. The synthesis of the phosphoramidite building block 18 was then completed via standard dimethoxytritylation $(\rightarrow \mathbf{1 7})$ followed by phosphitylation as described above.

\section{SCHEME 2. Synthesis of phosphoramidite 18}
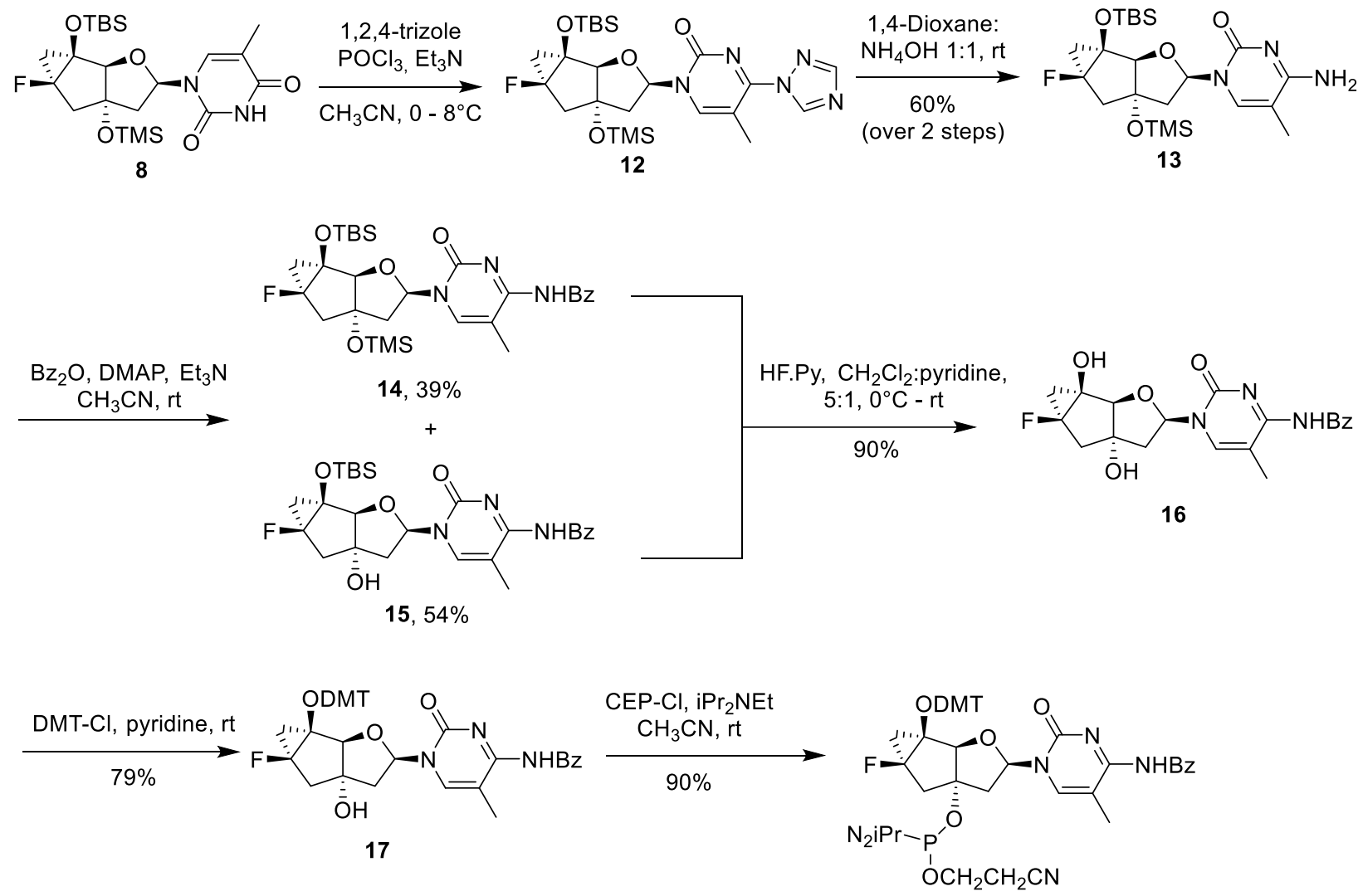

18

X-ray structure of $\mathbf{1 6}$. To confirm the relative configuration and to determine the effect of the fluorine substituent on the conformation of the tricyclic ring system, crystals of nucleoside $\mathbf{1 6}$ 
were grown and subjected to X-ray analysis. The molecular structure is depicted in Figure 2.
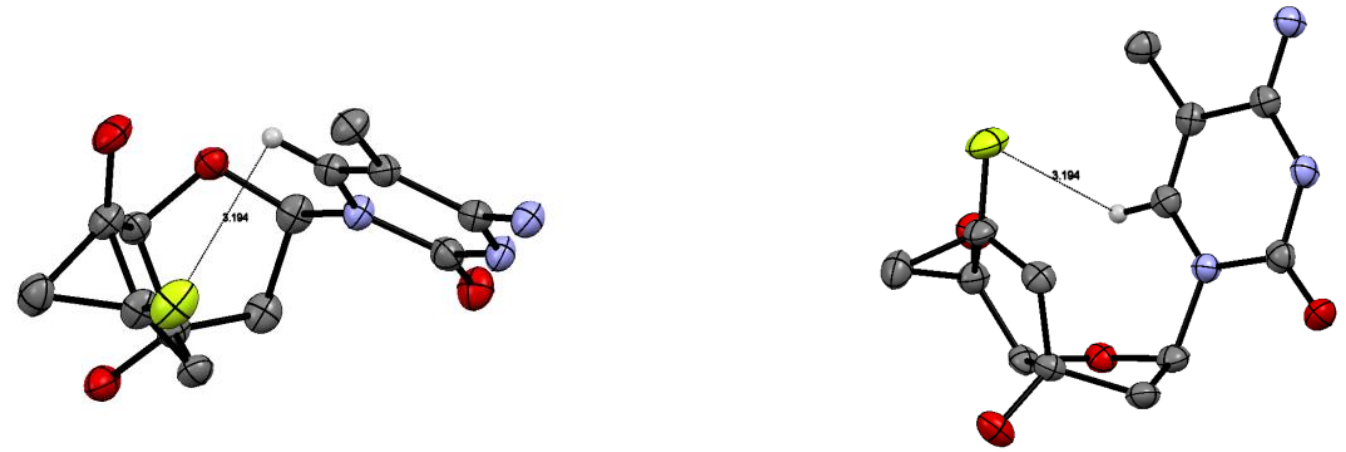

FIGURE 2. Ortep plot (50\% probability ellipsoids) of the X-ray structure of nucleoside 16: topview (left) and side-view (right). Non relevant hydrogen atoms as well as the $\mathrm{N}^{4}$-benzoyl residue in $\mathbf{1 6}$ are omitted for clarity.

The furanose unit in $\mathbf{1 6}$ adopts a 2'-exo conformation with a pseudorotation phase angle $P$ of $336^{\circ}$ and a maximum torsion angle $v_{\max }$ of $31^{\circ}$. It thus belongs clearly to the N-type conformation, typically adopted by RNA nucleosides. ${ }^{28}$ The base is oriented in the central antirange $\left(\chi=-176.2^{\circ}\right)$. Comparison of $\mathbf{1 6}$ with the structure of $6^{\prime}$-fluoro-bicyclo-T ${ }^{21}$ reveals two major differences: First, the distance F-H6 in $\mathbf{1 6}$ (3.194 $\AA$ ) is too long for a non-classical F-H hydrogen bond while the same distance in 6'-fluoro-bc-T $(2.865 \AA)$ is indicative for such a weak interaction. Furthermore, there is no linear arrangement of F-H6-C6 in 16, whereas this is clearly the case in 6'fluoro-bc-T. Support for the absence of such an interaction in $\mathbf{1 6}$ comes also from the fact that there are no F-H6 or F-C6 couplings observable in the ${ }^{1} \mathrm{H}$ - and ${ }^{13} \mathrm{C}-\mathrm{NMR}$ spectra of 16, which contrasts the findings in the case of 6'fluoro-bc-T. Thus, compared to 6'fluoro-bc-T, the base orienting H-F interaction of the fluorine is lost in 16. The second structural change resides within the furanose conformation, which is 1'-exo (S-type) in the case of 6'- 
fluorobicyclo-T and 2'-exo (N-type) in the case of 16. With respect to the non-fluorinated tricyclo-T nucleoside which coexists in a 2'-endo (S-type) and a 4'-endo (E-type) conformation in the crystal, ${ }^{29}$ it could well be that the fluoro atom helps to drive the furanose conformation of the tricyclic scaffold into a N-type conformation. We cannot exclude, however, that the higher propensity of $\mathrm{N}$-conformation in $\mathbf{1 6}$ is also simply an effect of the base 5-methyl cytosine.

Unfortunately, there are currently no X-ray structures for the non-fluorinated tc-C or tc- ${ }^{5 \mathrm{Me}} \mathrm{C}$ nucleosides available.

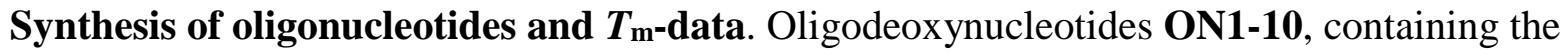
6'fluoro-tc-nucleosides, (Table 1) were synthesized on the $1.3 \mu \mathrm{mol}$ scale by standard phosphoramidite chemistry, utilizing the building blocks 11 and $\mathbf{1 8}$ (for details see experimental section). Crude oligonucleotides were deprotected and detached from solid support by standard ammonia treatment $\left(33 \% \mathrm{NH}_{4} \mathrm{OH}, 55^{\circ} \mathrm{C}\right.$, overnight $)$ and purified by ion exchange HPLC. The composition of all oligonucleotides was verified by ESI- mass spectrometry (Tables 1 and 3).

Table 1. Analytical data of oligodeoxynucleotides ON1-ON7, containing 6'fluoro-tc-T (t) or 6'fluoro-tc- ${ }^{5 \mathrm{Me}} \mathrm{C}(\underline{\mathbf{c}})$ units, as well as $T_{\mathrm{m}}$-data of duplexes with complementary DNA and RNA.

\begin{tabular}{lccccc}
\hline & & ESI-MS & ESI-MS & $T_{\mathrm{m}}\left({ }^{\circ} \mathrm{C}\right) v s \mathrm{DNA}^{\mathrm{a}, \mathrm{b}}$ & $T_{\mathrm{m}}\left({ }^{\circ} \mathrm{C}\right) v s \mathrm{RNA}^{\mathrm{a}, \mathrm{c}}$ \\
& & $m / z$ calc & $m / z$ found & $\left(\Delta T_{\mathrm{m}} / \mathrm{mod}\right)$ & $\left(\Delta T_{\mathrm{m}} / \mathrm{mod}\right)$ \\
\hline ON1 & $\mathrm{d}$ (AACTGtCACG) & 3067.6 & 3067.5 & $45.5(+2.0)$ & $44.4(0.0)$ \\
ON2 & $\mathrm{d}$ (AACtGTCACG) & 3067.6 & 3067.5 & $45.1(+1.6)$ & $45.4(+1.0)$ \\
ON3 & $\mathrm{d}$ (AACtGtCACG) & 3123.6 & 3123.5 & $43.5(0.0)$ & $44.3(0.0)$ \\
ON4 & $\mathrm{d}$ (GCAtttttACCG) & 3890.7 & 3890.6 & $43.1(-0.6)^{\mathrm{d}}$ & $45.6(+0.5)^{\mathrm{e}}$ \\
\hline
\end{tabular}




\begin{tabular}{|c|c|c|c|c|c|}
\hline ON5 & d(AACTGTéACG) & 3081.6 & 3081.5 & $44.6(+1.1)$ & $46.3(+1.9)$ \\
\hline ON6 & d(AA $\underline{\text { cTGTCACG) }}$ & 3081.6 & 3081.5 & $44.9(+1.4)$ & $48.9(+4.5)$ \\
\hline ON7 & d(AA $\underline{\mathbf{c} T G T} \underline{\mathbf{c}} \mathrm{ACG})$ & 3151.6 & 3151.6 & $48.2(+2.4)$ & $51.0(+3.3)$ \\
\hline
\end{tabular}

$\overline{\mathrm{a}}$ Total strand conc: $2 \mu \mathrm{M}$ in $10 \mathrm{mM} \mathrm{NaH}_{2} \mathrm{PO}_{4}, 150 \mathrm{mM} \mathrm{NaCl}, \mathrm{pH}$ 7.0. Estimated error in $T_{\mathrm{m}}=$ $\pm 0.5^{\circ} \mathrm{C} .{ }^{\mathrm{b}} T_{\mathrm{m}}$ of unmodified duplex: $43.5^{\circ} \mathrm{C} .{ }^{\mathrm{c}} T_{\mathrm{m}}$ of unmodified duplex: $44.4^{\circ} \mathrm{C} .{ }^{\mathrm{d}} T_{\mathrm{m}}$ of unmodified duplex: $46.3^{\circ} \mathrm{C}$. ${ }^{\text {e }} T_{\mathrm{m}}$ of unmodified duplex: $42.9^{\circ} \mathrm{C}$

Oligodeoxynucleotides containing single 6'fluoro tc-T mutations (ON1-3) lead to duplexes with complementary DNA and RNA with neutral to slightly enhanced stability in a slightly sequence dependent context, compared to unmodified duplexes. Interestingly, the stabilization $\left(\Delta T_{\mathrm{m}} / \bmod\right.$. $)$ is a bit stronger in duplexes with complementary DNA as compared to RNA. Double substitutions in a non-contiguous order (ON3) tendentially lead to poorer duplex stabilization with RNA compared to multiple substitutions in a consecutive manner (ON4). This is in agreement with earlier observations in the series of tc-DNA, ${ }^{30}$ and has been ascribed to an incremental energetic penalty arising from increasing numbers of structural hetrobackbone junctions. Replacing natural dC with 6'fluoro-tc- ${ }^{5 \mathrm{Me}} \mathrm{C}$ units (ON5-7) leads to a somewhat different picture. Again, in a slightly sequence dependent context, duplex stabilization is significantly higher (up to $+4.5^{\circ} \mathrm{C} / \mathrm{mod}$ ) as compared to $\mathrm{dC}$ and more pronounced with RNA as a complement. In addition, there seems to be almost no energetic penalty as a function of the number of non-contiguous substitutions (ON5 and ON6 vs ON7). While it is known that the base thymine in the tc-DNA context is least stabilizing compared to the other three bases, ${ }^{30,31}$ the origin of this effect is yet unknown and awaits further structural investigations. 
To elucidate the role of the fluorine atom and the methyl group in 5-methyl cytosine on RNA duplex stability we compared $\Delta T_{\mathrm{m}} / \bmod$ data with that of oligonucleotides containing tc-T, tc-C and tc- ${ }^{5 \mathrm{Me}} \mathrm{C}$ residues, resp. (Table 2). From this set of data it becomes evident that in both the Tand C-series, the 6'-fluorine atom behaves neutral and does not significantly add to duplex stability. This is in agreement with the absence of any F-H5 pseudo-hydrogen bond, as found in the X-ray structure of 16, and supports our earlier hypothesis that this interaction is responsible for the increase in stability in the bc-DNA series. ${ }^{21}$ At the same time it is in agreement with the properties of other 6'-modified tc-DNA derivatives for which it was shown before that this position can be chemically modified without compromising RNA affinity. ${ }^{24}$ In the C-series, the 5-methyl group of cytosine brings about $0.2-1.2{ }^{\circ} \mathrm{C} / \mathrm{mod}$ of additional thermal stability also in the context of the tricyclic nucleoside structure. As for the case of 5-methyldeoxycytidine in DNA duplexes, this is most likely the consequence of improved stacking interactions and/or improved hydrogen bonding induced by the molecular polarizability of the size extended base. ${ }^{32}$

Table 2. Structure affinity relationship: $\Delta T_{\mathrm{m}} / \bmod$ data for oligodeoxynucleotides containing parent or substituted tc-nucleosides in complex with complementary RNA.

\begin{tabular}{|c|c|c|c|c|c|c|}
\hline $\mathrm{X}$ & tc-T & 6'F-tc-T & & tc-C & tc $-{ }^{5 \mathrm{Me}} \mathrm{C}$ & $5^{\prime} \mathrm{F}-\mathrm{tc}-{ }^{5 \mathrm{Me}} \mathrm{C}$ \\
\hline d(AACTGXCACG) & -0.1 & 0.0 & d(AACTGTXACG) & +2.0 & +2.2 & +1.9 \\
\hline d(AACXGTCACG) & +1.4 & +1.0 & d(AAXTGTCACG) & +3.0 & +4.2 & +4.5 \\
\hline d(AACXGXCACG) & +0.4 & 0.0 & d(AAXTGTXACG) & +2.5 & +3.6 & +3.3 \\
\hline
\end{tabular}

Experimental conditions as in Table1.

In the context of future applications as steric block or splice switching oligonucleotides we investigated also the fully modified tc-oligonucleotides ON8-10 containing 6'-fluoro-tc-T units. 
These oligonucleotides all carry a 5'-phosphate unit in order to confer chemical stability to the 5' -terminal nucleoside unit during oligonucleotide deprotection. ${ }^{33}$ As can be seen from Table 3, duplexes with complementary DNA (non 5'-phosphorylated) are somewhat destabilized in the presence of the fluorine atom, while a slight stabilization in a sequence dependent manner occurs with RNA (non 5'-phosphorylated) as complement. Thus 6'-fluorination is fully compatible with the tc-DNA backbone and does not lead to loss of RNA affinity.

Table 3. Analytical data of tc-oligonucleotides ON8-ON10, containing 6'-fluoro-tc-T (t), and $T_{\mathrm{m}}$-data of duplexes with complementary DNA and RNA.

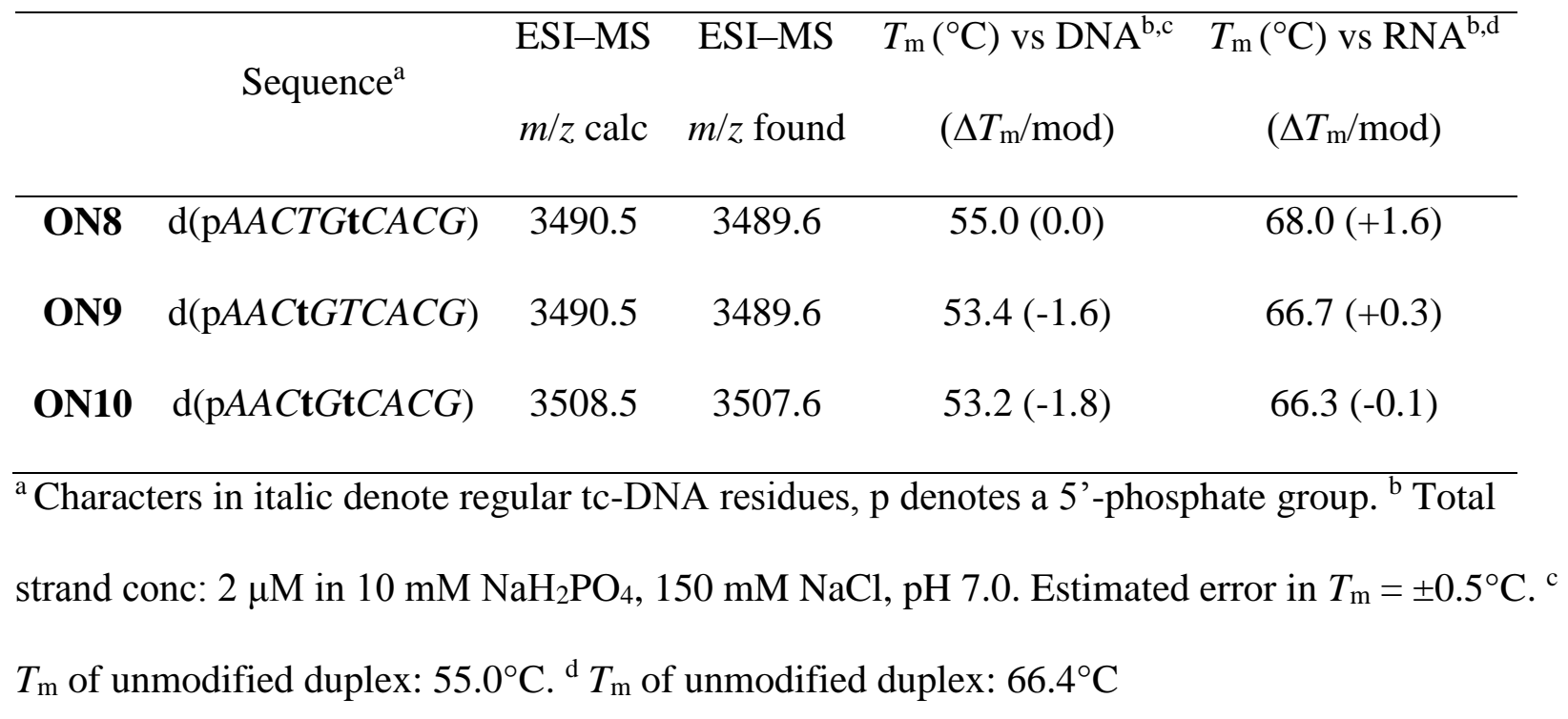

To determine the effect of 6'F-tc-T units on duplex conformation we measured CD spectra of duplexes of ON4 with complementary DNA and RNA and compared them with the corresponding unmodified duplexes and with duplexes containing tc-T instead of 6'F-tc-T units (Figure 3). The largest structural deviation occurs in the DNA/DNA duplex series where both, the 6'F-tc-T and the tc-T units drive the duplex conformation from B to A-like. There are no 
significant differences between duplexes with tc-T or 6'fluoro-tc-T, indicating that both adopt an N-type nucleoside conformation. The tendency to adopt a more A-like conformation in duplexes with tc-T or 6'F-tc-T units is also present in the DNA/RNA duplex series. Again, there are no large differences between the tc-T and 6'F-tc-T containing duplexes, perhaps with the exception that the maximum positive ellipticity around $270 \mathrm{~nm}$ is blue shifted by ca $10 \mathrm{~nm}$ in the case of the latter duplex, with a yet unknown implication on the helix structure.

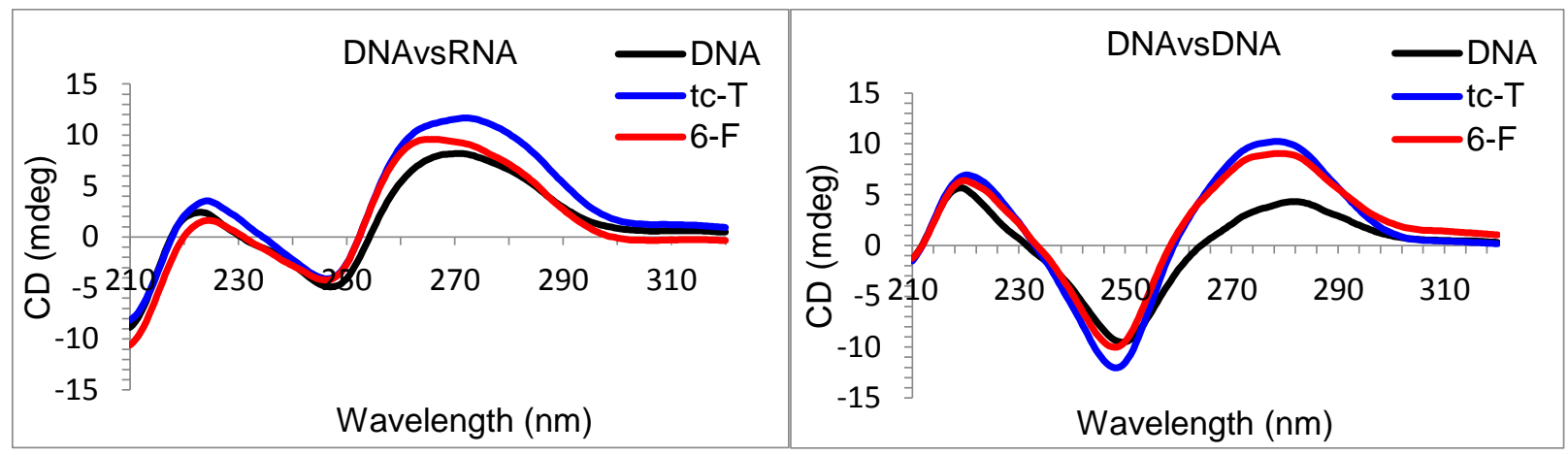

FigURE 3. CD-spectra of left: DNA/RNA duplexes and right: DNA/DNA duplexes. Black lines: unmodified duplexes, red lines duplexes with ON4, and blue lines duplexes with ON4 in which 6'-fluoro-tc-T was replaced by tc-T. Experimental conditions as indicated in Table 1.

\section{Conclusion:}

We have accomplished the synthesis of the two 6'fluorinated tc-nucleoside building blocks $\mathbf{1 1}$ and 18 and have incorporated them into oligodeoxynucleotides and tc-oligonucleotides. We analyzed complementary DNA and RNA affinity by $T_{\mathrm{m}}$-measurements and determined structural effects of fluorine substitution on duplex conformation by CD spectroscopy. Based on the X-ray structure of 16 as well as on ${ }^{1} \mathrm{H}$ - and ${ }^{13} \mathrm{C}-\mathrm{NMR}$ coupling data on the nucleosides and derivatives we could not find any indications for short fluorine-base F-H6 contacts. This is in surprising 
contrast to findings in the 6'-fluoro-bc-DNA series, where such short contacts were observed. Compared to the non-fluorinated tc-nucleosides we find that the fluorine substituent does not significantly alter the thermal melting properties of the corresponding duplexes, irrespective of the nature of the base (thymine vs 5-methylcytosine). This is in agreement with the absence of the glycosidic bond constraining nature of the F-H6 interaction that adds up to $+2{ }^{\circ} \mathrm{C} / \mathrm{mod}$ in $T_{\mathrm{m}}$ in the case of the bicyclo-DNA series. The 6'-fluoro modification is also compatible with the tc-DNA backbone as no change or even a slight increase in $T_{\mathrm{m}}$ with complementary RNA was observed. The fluorine atom does also not significantly alter the duplex conformation compared to nonfluorinated tc-DNA as can be seen from the corresponding CD-spectra. Based on these encouraging biophysical data we are now planning to investigate functional efficacy, cellular uptake and in vivo tissue distribution of antisense tc-oligonucleotides containing these 6'F-tcnucleosides.

\section{Experimental Section}

General Methods. All reactions were performed under argon in oven dried glassware. Solvents were dried by filtration over activated alumina or by storage over molecular sieves ( $4 \AA$ ). Column chromatography (CC) was performed on silica gel 60 (230-400 mesh, neutralized with $0.1 \%$ of w/Ca). All solvents for CC were of technical grade and distilled prior to use. Thin-layer chromatography (TLC) was performed on silica gel plates. Compounds were visualized either under UV light or by staining in dip solution $\mathrm{A}$ : $\mathrm{Cer}^{\mathrm{IV}}$-sulfate $(10.5 \mathrm{~g})$, phosphormolybdenic acid (21 g), conc. $\mathrm{H}_{2} \mathrm{SO}_{4}(60 \mathrm{~mL}), \mathrm{H}_{2} \mathrm{O}(900 \mathrm{~mL})$; or B: $\mathrm{KMnO}_{4}(6 \mathrm{~g}), \mathrm{K}_{2} \mathrm{CO}_{3}(40 \mathrm{~g}), 15 \% \mathrm{NaOH}(3$ $\mathrm{mL})$ in $\left.\mathrm{H}_{2} \mathrm{O}(800 \mathrm{~mL})\right)$, followed by heating with a heat gun. NMR spectra were recorded at 300 or $400 \mathrm{MHz}\left({ }^{1} \mathrm{H}\right)$, at $75 \mathrm{MHz}$ or $100 \mathrm{MHz}\left({ }^{13} \mathrm{C}\right)$, at $376 \mathrm{MHz}\left({ }^{19} \mathrm{~F}\right)$ and at $162 \mathrm{MHz}\left({ }^{31} \mathrm{P}\right)$. Chemical 
shifts $(\delta)$ are reported relative to the undeuterated residual solvent peak $\left(\mathrm{CHCl}_{3}: 7.24 \mathrm{ppm}\left({ }^{1} \mathrm{H}\right)\right.$ and $77.2 \mathrm{ppm}\left({ }^{13} \mathrm{C}\right)$; DMSO-d6: $2.50 \mathrm{ppm}\left({ }^{1} \mathrm{H}\right)$ and $\left.39.5 \mathrm{ppm}\left({ }^{13} \mathrm{C}\right)\right)$. Signal assignments are based on DEPT or APT experiments, and on ${ }^{1} \mathrm{H},{ }^{1} \mathrm{H}$ - and ${ }^{1} \mathrm{H},{ }^{13} \mathrm{C}$-correlation experiments (COSY, HSQC). ${ }^{13} \mathrm{C}$ signal multiplicities include ${ }^{1} \mathrm{H}$ - and ${ }^{19} \mathrm{~F}$-couplings. ${ }^{1} \mathrm{H}$-NMR difference-NOESY experiments were recorded at $400 \mathrm{MHz}$. Chemical shifts for ${ }^{31} \mathrm{P}$ and ${ }^{19} \mathrm{~F}$ NMR (fully proton coupled) are reported relative to $85 \% \mathrm{H}_{3} \mathrm{PO}_{4}$ and $\mathrm{CFCl}_{3}$ as external standards, respectively. Electrospray ionization in the positive mode (ion trap, $\mathrm{ESI}^{+}$) was used for high resolution mass detection. The numbering scheme for tc-nucleosides is outlined in Figure 1. For non-nucleoside derivatives the von Baeyer nomenclature has been applied.

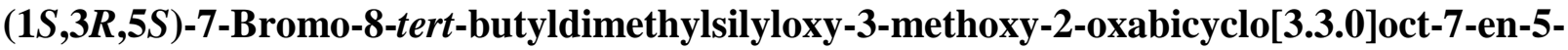

ol (2). To a stirred solution of silylenolether $\mathbf{1}(10.6 \mathrm{~g}, 37.0 \mathrm{mmol})$ in dry $\mathrm{CH}_{2} \mathrm{Cl}_{2}(100 \mathrm{~mL})$ was added dropwise a solution of bromine $(2.1 \mathrm{~mL}, 40.7 \mathrm{mmol})$ in $\mathrm{CH}_{2} \mathrm{Cl}_{2}(200 \mathrm{~mL})$ over a period of $30 \mathrm{~min}$ at $-78^{\circ} \mathrm{C}$, followed by $\mathrm{Et}_{3} \mathrm{~N}(7.7 \mathrm{~mL}, 55.48 \mathrm{mmol})$. The cooling bath was subsequently removed and the temperature was allowed to rise to rt. Stirring was continued for another $2 \mathrm{~h}$. Then the reaction mixture was poured into $\mathrm{H}_{2} \mathrm{O}$ and extracted with $\mathrm{Et}_{2} \mathrm{O}$. The combined organic layers were washed with water, dried over $\mathrm{MgSO}_{4}$ and evaporated. The residual dark oil was purified by CC (hexane/EtOAc 4:1) to give the title compound 2 (12.1 g, 90\%) as a yellow oil.

Data for 2. $R_{f}=0.33\left(\right.$ hexane/EtOAc 7:3); ${ }^{1} \mathrm{H} \mathrm{NMR}\left(\mathrm{CDCl}_{3}, 300 \mathrm{MHz}\right) \delta 5.04(\mathrm{~d}, J=4.1 \mathrm{~Hz}, 1 \mathrm{H}$, H-C(3)), 4.57 (m, 1H, H-C(1)), 3.37 (s, 3H, OMe), 3.15 (s, 1H, OH), 2.76 (d, J = $15.3 \mathrm{~Hz}, 1 \mathrm{H}$, $\left.\mathrm{H}_{\mathrm{b}}-\mathrm{C}(6)\right), 2.67\left(\mathrm{dd}, J=2.2,15.3 \mathrm{~Hz}, 1 \mathrm{H}, \mathrm{H}_{\mathrm{a}}-\mathrm{C}(6)\right), 2.25\left(\mathrm{~d}, J=13.5 \mathrm{~Hz}, 1 \mathrm{H}, \mathrm{H}_{\mathrm{b}}-\mathrm{C}(4)\right), 2.02(\mathrm{dd}, J$ $\left.=4.1,13.5 \mathrm{~Hz}, 1 \mathrm{H}, \mathrm{H}_{\mathrm{a}}-\mathrm{C}(4)\right), 0.97(\mathrm{~s}, 9 \mathrm{H}, t-\mathrm{Bu}), 0.24,0.20\left(2 \mathrm{~s}, 2 \mathrm{x} 3 \mathrm{H}, 2 \mathrm{xCH}_{3}\right) ;{ }^{13} \mathrm{C} \mathrm{NMR}\left(\mathrm{CDCl}_{3}\right.$, $75 \mathrm{MHz}) \delta 148.4(\mathrm{~s}, \mathrm{C}(8)), 105.3(\mathrm{~d}, \mathrm{C}(3)), 96.7$ (s, C(7)), 90.4 (d, C(1)), 83.4 (s, C(5)), 54.7 (q, OMe), $47.2(\mathrm{t}, \mathrm{C}(6)), 44.8(\mathrm{t}, \mathrm{C}(4)), 25.8$ (q, $t$-Bu), $18.4(\mathrm{~s}, t-\mathrm{Bu}),-3.9,-4.2\left(2 \mathrm{xs}, 2 \mathrm{xCH}_{3}\right)$; $\mathrm{ESI}^{+}-$ HRMS $m / z$ calcd for $\mathrm{C}_{14} \mathrm{H}_{25} \mathrm{BrNaO}_{4} \mathrm{Si}[\mathrm{M}+\mathrm{Na}]^{+}$387.0603, 389.0583, found 387.0598, 389.0577. 


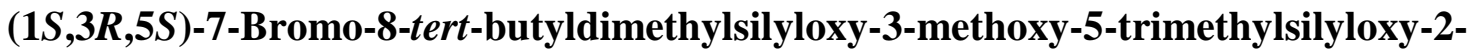

oxabicyclo[3.3.0]oct-7-en (3). To a stirred solution of bromosilylenolether 2 (12.0 g, 32.74

mmol) in dry pyridine $(170 \mathrm{~mL})$ was added BSA $(12 \mathrm{~mL}, 49.11 \mathrm{mmol})$ at $\mathrm{rt}$ and the mixture left overnight. The reaction mixture was diluted with sat aq $\mathrm{NaHCO}_{3}$ and extracted with $\mathrm{Et}_{2} \mathrm{O}$. The combined organic layers were dried over $\mathrm{MgSO}_{4}$, evaporated and the residual oil purified by CC (hexane/EtOAc 95:5, with $0.5 \%$ of $\left.\mathrm{Et}_{3} \mathrm{~N}\right)$ to yield the title compound $\mathbf{3}(13.0 \mathrm{~g}, 91 \%) \mathrm{s}$ a yellow oil.

Data for 3. $R_{f}=0.68\left(\right.$ hexane/EtOAc 9:1); ${ }^{1} \mathrm{H}$ NMR $\left(\mathrm{CDCl}_{3}, 300 \mathrm{MHz}\right) \delta 4.99(\mathrm{dd}, J=1.3,5.3$ Hz, 1H, H-C(3)), 4.64 (t, J=1.4 Hz, 1H, H-C(1)), 3.35 (s, 3H, OMe), 2.73 (d, J = 1.5 Hz, 2H, H$\mathrm{C}(6)), 2.33\left(\mathrm{dd}, J=1.3,13.7 \mathrm{~Hz}, 1 \mathrm{H}, \mathrm{H}_{\mathrm{b}} \mathrm{C}(4)\right), 2.06\left(\mathrm{dd}, J=5.3,13.7 \mathrm{~Hz}, 1 \mathrm{H}, \mathrm{H}_{\mathrm{a}}-\mathrm{C}(4)\right), 0.97$ (s, 9H, $t$-Bu), 0.24, $0.21\left(2 \mathrm{~s}, 2 \times 3 \mathrm{H}, 2 \times \mathrm{CH}_{3}\right), 0.15$ (s, 9H, TMS); ${ }^{13} \mathrm{C} \mathrm{NMR}\left(\mathrm{CDCl}_{3}, 75 \mathrm{MHz}\right) \delta 148.6$ (s, C(8)), 105.7 (d, C(3)), 96.4 (s, C(7)), 90.3 (d, C(1)), 84.8 (s, C(5)), 55.2 (q, OMe), 49.5 (t, $\mathrm{C}(6)), 48.4(\mathrm{t}, \mathrm{C}(4)), 25.8(\mathrm{q}, t-\mathrm{Bu}), 18.4(\mathrm{~s}, t-\mathrm{Bu}), 1.9$ (q, TMS), -3.9, -4.2 (2q, 2xCH$)$; ESI+HRMS $m / z$ calcd for $\mathrm{C}_{17} \mathrm{H}_{33} \mathrm{BrNaO}_{4} \mathrm{Si}_{2}[\mathrm{M}+\mathrm{Na}]^{+}$459.0998, 461.0978, found 459.1002, 461.0981 .

\section{$(1 S, 3 R, 5 S)$-7-Fluoro-8-tert-butyldimethylsilyloxy-3-methoxy-2-oxabicyclo[3.3.0]oct-7-en-5-ol}

(4). To a stirred solution of bromosilylenolether $3(6.14 \mathrm{~g}, 14.04 \mathrm{mmol})$ in dry THF (211 mL) and ether $(42 \mathrm{~mL})$ was added dropwise a solution of $t$-BuLi (1.7 M in pentane, $16.5 \mathrm{~mL}, 28.08 \mathrm{mmol})$ at $-78^{\circ} \mathrm{C}$. After stirring for $20 \mathrm{~min}$ the reaction mixture was further cooled to $-120^{\circ} \mathrm{C}$ and NFSI $(8.85 \mathrm{~g}, 28.08 \mathrm{mmol})$ was added at once, followed by another portion of $t$-BuLi $(24.8 \mathrm{~mL}, 42.12$ $\mathrm{mmol})$. The reaction mixture was stirred for 2 hours and then allowed to warm up to $-80^{\circ} \mathrm{C}$. After 
quenching with water $(210 \mathrm{~mL})$ the mixture was warmed up to $\mathrm{rt}$ and extracted with EtOAc. The combined organic phases were dried over $\mathrm{MgSO}_{4}$ and evaporated. The residue was then dissolved in dry ether $(200 \mathrm{~mL})$, treated with amberlyst $15(6.1 \mathrm{~g})$ and the mixture stirred for 2 hours at rt. The amberlyst was then filtered off and $\mathrm{SiO}_{2}$ was added to the filtrate prior to evaporation. Purification by $\mathrm{CC}\left(\mathrm{CH}_{2} \mathrm{Cl}_{2}\right.$ /hexane $\left.7: 3 \rightarrow \mathrm{CH}_{2} \mathrm{Cl}_{2},+1 \% \mathrm{Et}_{2} \mathrm{O}\right)$ gave the title comound $4(2.56 \mathrm{~g}, 60 \%)$ in form of a yellowish solid.

Data for 4. $R_{f}=0.53($ hexane/EtOAc $3: 1) ;{ }^{1} \mathrm{H} \mathrm{NMR}\left(\mathrm{CDCl}_{3}, 300 \mathrm{MHz}\right) \delta 5.05(\mathrm{~d}, J=4.1 \mathrm{~Hz}, 1 \mathrm{H}$, H-C(3)), 4.58 (dt, $J=1.8,8.0 \mathrm{~Hz}, 1 \mathrm{H}, \mathrm{H}-\mathrm{C}(1)), 3.38$ (s, 3H, OMe), 3.11 (d, $J=2.3 \mathrm{~Hz}, 1 \mathrm{H}, \mathrm{OH})$, $2.62(\mathrm{~m}, 2 \mathrm{H}, \mathrm{H}-\mathrm{C}(6)), 2.28\left(\mathrm{~d}, J=13.4 \mathrm{~Hz}, 1 \mathrm{H}, \mathrm{H}_{\mathrm{b}}-\mathrm{C}(4)\right), 1.97\left(\mathrm{dd}, J=4.1,13.4 \mathrm{~Hz}, 1 \mathrm{H}, \mathrm{H}_{\mathrm{a}^{-}}\right.$ $\mathrm{C}(4)), 0.95(\mathrm{~s}, 9 \mathrm{H}, t-\mathrm{Bu}), 0.19,0.17\left(2 \mathrm{~s}, 2 \mathrm{x} 3 \mathrm{H}, 2 \mathrm{xCH}_{3}\right) ;{ }^{13} \mathrm{C} \mathrm{NMR}\left(\mathrm{CDCl}_{3}, 75 \mathrm{MHz}\right) \delta 138.5(\mathrm{~d}, J$ $(C, F)=272.2 \mathrm{~Hz}, \mathrm{C}(7)), 128.6(\mathrm{~d}, J(C, F)=4.0 \mathrm{~Hz}, \mathrm{C}(8)), 104.8(\mathrm{~d}, \mathrm{C}(3)), 89.9(\mathrm{dd}, J(C, F)=$ $5.3 \mathrm{~Hz}, \mathrm{C}(1)), 79.7(\mathrm{~d}, J(C, F)=11.6 \mathrm{~Hz}, \mathrm{C}(5)), 54.7(\mathrm{q}, \mathrm{OMe}), 47.5(\mathrm{t}, \mathrm{C}(4)), 37.4(\mathrm{td}, J(C, F)=$ 18.6 Hz, C(6)), 25.7 (q, $\left.t-\mathrm{Bu}), 18.3(\mathrm{~s}, t-\mathrm{Bu}),-4.3(\mathrm{qd}, J=1.7 \mathrm{~Hz}), \mathrm{CH}_{3}\right),-4.56(\mathrm{qd}, J=2.1 \mathrm{~Hz}$, $\left.\mathrm{CH}_{3}\right) ;{ }^{19} \mathrm{~F} \mathrm{NMR}\left(\mathrm{CDCl}_{3}, 376 \mathrm{MHz}\right) \delta-138.5$ (s, br); ESI ${ }^{+}-\mathrm{HRMS} m / z$ calcd for $\mathrm{C}_{14} \mathrm{H}_{25} \mathrm{FNaO}_{4} \mathrm{Si}$ $[\mathrm{M}+\mathrm{Na}]^{+}$327.1404, found 327.1412 .

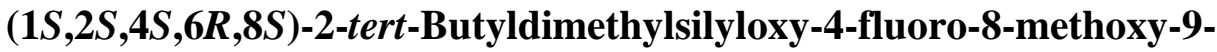

oxatricyclo[4.3.0 $\left.{ }^{1.6} \cdot 0^{\mathbf{2 . 4}}\right]$ nonane-6-ol (5). To dry $\mathrm{CH}_{2} \mathrm{Cl}_{2}(97 \mathrm{~mL})$ was added a solution of $\mathrm{Et}_{2} \mathrm{Zn}$ (1 $\mathrm{M}$ in hexane, $48.2 \mathrm{~mL} 48.20 \mathrm{mmol}$ ). The mixture was cooled to $0^{\circ} \mathrm{C}$ and a solution of TFA (3.69 mL, $48.21 \mathrm{mmol}$ ) in $\mathrm{CH}_{2} \mathrm{Cl}_{2}(48 \mathrm{~mL})$ was slowly added. After stirring for $20 \mathrm{~min}$ a solution of $\mathrm{CH}_{2} \mathrm{I}_{2}(7.76 \mathrm{~mL}, 96.42 \mathrm{mmol})$ in $\mathrm{CH}_{2} \mathrm{Cl}_{2}(48 \mathrm{~mL})$ was added. After another $20 \mathrm{~min}$ of stirring, a solution of fluorosilylenolether $4(2.45 \mathrm{~g}, 8.04 \mathrm{mmol})$ in $\mathrm{CH}_{2} \mathrm{Cl}_{2}(48 \mathrm{~mL})$ was added, and the ice bath was removed. After 5 hours of stirring, the reaction mixture was quenched with sat aq $\mathrm{NH}_{4} \mathrm{Cl}$ and the layers separated. The aqueous layer was extracted with $\mathrm{CH}_{2} \mathrm{Cl}_{2}$. The combined 
organic layers were washed with sat $\mathrm{NaHCO}_{3}$, dried over $\mathrm{MgSO}_{4}$, concentrated, and purified by $\mathrm{CC}$ (hexane/EtOAc, 9:1) to yield the title compound $5(1.79 \mathrm{~g}, 70 \%)$ as a colorless oil.

Data for 5. $R_{f}=0.33\left(\right.$ hexane/EtOAc 3:1); ${ }^{1} \mathrm{H}$ NMR $\left(\mathrm{CDCl}_{3}, 300 \mathrm{MHz}\right) \delta 5.10(\mathrm{dd}, J=1.6,5.2$ Hz, 1H, H-C(8)), 3.89 (d, J=6.0 Hz, 1H, H-C(1)), 3.37 (s, 3H, OMe), 2.49 (m, 1H, H $-\mathrm{C}(5))$, $2.43\left(\mathrm{dd}, J=5.3,14.0 \mathrm{~Hz}, 1 \mathrm{H}, \mathrm{H}_{\mathrm{b}}-\mathrm{C}(7)\right), 2.29\left(\mathrm{dd}, J=1.1 \mathrm{~Hz}, J=13.4 \mathrm{~Hz}, 1 \mathrm{H}, \mathrm{H}_{\mathrm{a}}-\mathrm{C}(5)\right), 2.10(\mathrm{~s}$, br, $1 \mathrm{H}, \mathrm{OH}), 2.06\left(\mathrm{dd}, J=1.6,14.0 \mathrm{~Hz}, 1 \mathrm{H}, \mathrm{H}_{\mathrm{a}}-\mathrm{C}(7)\right), 1.33\left(\mathrm{ddd}, J=2.5,7.5,21.5 \mathrm{~Hz}, 1 \mathrm{H}, \mathrm{H}_{\mathrm{b}^{-}}\right.$ $\mathrm{C}(3)), 1.19\left(\mathrm{dd}, J=7.5,8.5 \mathrm{~Hz}, 1 \mathrm{H}, \mathrm{H}_{\mathrm{a}}-(3)\right), 0.91(\mathrm{~s}, 9 \mathrm{H}, t-\mathrm{Bu}), 0.17\left(\mathrm{~s}, 6 \mathrm{H}, 2 \mathrm{xCH}_{3}\right) ;{ }^{13} \mathrm{C} \mathrm{NMR}$ $\left(\mathrm{CDCl}_{3}, 75 \mathrm{MHz}\right) \delta 105.7(\mathrm{~d}, \mathrm{C}(8)), 88.7(\mathrm{dd}, J(C, F)=3.8 \mathrm{~Hz}, \mathrm{C}(1)), 83.2(\mathrm{~d}, J(C, F)=268.2$ $\mathrm{Hz}, \mathrm{C}(4)), 82.1(\mathrm{~d}, J(C, F)=5.5 \mathrm{~Hz}, \mathrm{C}(6)), 63.7(\mathrm{~d}, J(C, F)=8.3 \mathrm{~Hz}, \mathrm{C}(2)), 54.9(\mathrm{q}, \mathrm{OMe}), 49.9$ $(\mathrm{t}, \mathrm{C}(7)), 44.4(\mathrm{td}, J(C, F)=16.5 \mathrm{~Hz}, \mathrm{C}(5)), 25.9(\mathrm{q}, t-\mathrm{Bu}), 21.7(\mathrm{td}, J(C, F)=10.3 \mathrm{~Hz}, \mathrm{C}(3))$, $18.3(\mathrm{~s}, t-\mathrm{Bu}),-3.9\left(\mathrm{q}, \mathrm{CH}_{3}\right),-4.0\left(\mathrm{qd}, J(C, F)=1.8 \mathrm{~Hz}, \mathrm{CH}_{3}\right) ;{ }^{19} \mathrm{~F} \mathrm{NMR}\left(\mathrm{CDCl}_{3}, 376 \mathrm{MHz}\right) \delta-$ 194.9 (m); $\mathrm{ESI}^{+}-\mathrm{HRMS} m / z$ calcd for $\mathrm{C}_{15} \mathrm{H}_{27} \mathrm{FNaO}_{4} \mathrm{Si}[\mathrm{M}+\mathrm{Na}]^{+} 341.1560$, found 341.1561 .

\section{$(1 S, 2 S, 4 S, 6 R)-2$-tert-Butyldimethylsilyloxy-4-fluoro-6-trimethylsilyloxy-9-}

oxatricyclo[4.3.0 $\left.{ }^{\mathbf{1 . 6}} .^{\mathbf{2 . 4}}\right]$ non-7-ene (6). To a solution of compound $\mathbf{5}(1.51 \mathrm{~g}, 4.38 \mathrm{mmol})$ and 2,6-lutidine $(2.80 \mathrm{~mL}, 24.20 \mathrm{mmol})$ in dry $\mathrm{CH}_{2} \mathrm{Cl}_{2}(10 \mathrm{~mL})$ was added TMSOTf $(2.14 \mathrm{~mL}, 11.84$ mmol) dropwise at $0^{\circ} \mathrm{C}$. After stirring for $2.5 \mathrm{~h}$ at $\mathrm{rt}$, the reaction mixture was diluted with AcOEt, washed with saturated $\mathrm{NaHCO}_{3}$ and the aqueous phase extracted with AcOEt. The combined organic phases were dried over $\mathrm{MgSO}_{4}$, evaporated and the residue purified by $\mathrm{CC}$ (hexane/Et $2 \mathrm{O} 95: 5)$ to give the title compound $6(1.43 \mathrm{~g}, 91 \%)$ as light brownish oil.

Data for 6. $R_{f}=0.83($ hexane/EtOAc $4: 1) ;{ }^{1} \mathrm{H} \mathrm{NMR}\left(\mathrm{CDCl}_{3}, 300 \mathrm{MHz}\right) \delta 6.33(\mathrm{~d}, J=2.7 \mathrm{~Hz}, 1 \mathrm{H}$, H-C(8)), 5.15 (d, $J=2.7 \mathrm{~Hz}, 1 \mathrm{H}, \mathrm{H}-\mathrm{C}(7)), 4.24$ (d, $J=6.0 \mathrm{~Hz}, 1 \mathrm{H}, \mathrm{H}-\mathrm{C}(1)), 2.52$ (ddd, $J=2.8$, 11.6, 12.9 Hz, 1H, $\left.\mathrm{H}_{\mathrm{b}}-\mathrm{C}(5)\right), 2.37$ (dd, $\left.J=1.1,12.9 \mathrm{~Hz}, 1 \mathrm{H}, \mathrm{H}_{\mathrm{a}}-\mathrm{C}(5)\right), 1.45$ (ddd, $J=2.8,7.4$, 
$\left.10.1 \mathrm{~Hz}, 1 \mathrm{H}, \mathrm{H}_{\mathrm{b}} \mathrm{C}(3)\right), 1.02\left(\mathrm{dd}, J=7.4,8.4 \mathrm{~Hz}, 1 \mathrm{H}, \mathrm{H}_{\mathrm{a}}-\mathrm{C}(3)\right), 0.90$ (s, 9H, $\left.t-\mathrm{Bu}\right), 0.15,0.11$ (2s, $\left.2 \times 3 \mathrm{H}, 2 \mathrm{xCH}_{3}\right), 0.09$ (s, 9H, TMS); ${ }^{13} \mathrm{C} \mathrm{NMR}\left(\mathrm{CDCl}_{3}, 75 \mathrm{MHz}\right) \delta 146.7(\mathrm{~d}, \mathrm{C}(8)), 108.4(\mathrm{~d}, \mathrm{C}(7))$, $94.1(\mathrm{dd}, J(C, F)=4.1 \mathrm{~Hz}, \mathrm{C}(1)), 87.1(\mathrm{~d}, J(C, F)=14.2 \mathrm{~Hz}, \mathrm{C}(6)), 84.4(\mathrm{~d}, J(C, F)=250.2 \mathrm{~Hz}$, $\mathrm{C}-(4)), 64.8(\mathrm{~d}, J(C, F)=8.4 \mathrm{~Hz}, \mathrm{C}(2)), 48.7(\mathrm{td}, J(C, F)=14.4 \mathrm{~Hz}, \mathrm{C}(5)), 26.0(\mathrm{q}, t-\mathrm{Bu}), 22.9$ $(\mathrm{td}, J(C, F)=10.6 \mathrm{~Hz}, \mathrm{C}(3)), 18.4(\mathrm{~s}, t-\mathrm{Bu}), 2.0(\mathrm{q}, \mathrm{TMS}),-3.8\left(\mathrm{q}, \mathrm{CH}_{3}\right),-4.3(\mathrm{qd}, J(C, F)=2.8$ $\left.\mathrm{Hz}, \mathrm{CH}_{3}\right) ;{ }^{19} \mathrm{~F} \mathrm{NMR}\left(\mathrm{CDCl}_{3}, 376 \mathrm{MHz}\right) \delta-192.6(\mathrm{~m})$; ESI ${ }^{+}-\mathrm{HRMS} m / z$ calcd for $\mathrm{C}_{17} \mathrm{H}_{32} \mathrm{FO}_{3} \mathrm{Si}_{2}$ $[\mathrm{M}+\mathrm{H}]^{+} 359.1874$, found 359.1873 .

\section{$\left(5^{6}-O\right.$-(tert-Butyldimethylsilyl)- $3^{6}-O$-(trimethylsilyl)-2'-deoxy-36,5'-ethano-6'-fluoro-2 ${ }^{6}-$} iodo-5',6'-methano- $\beta$-D-ribofuranosy)thymine (7). To a suspension of thymine $(1.49 \mathrm{~g}, 11.80$ mmol $)$ and compound $6(1.41 \mathrm{~g}, 3.93 \mathrm{mmol})$ in $\mathrm{CH}_{2} \mathrm{Cl}_{2}(20 \mathrm{~mL})$ was added BSA $(2.88 \mathrm{ml}, 11.80$ mmol) and the mixture was stirred at $\mathrm{rt}$ for $2 \mathrm{~h}$ to become a clear solution. Then $\mathrm{N}$ iodsuccinimide $(1.32 \mathrm{~g}, 5.90 \mathrm{mmol})$ was added and the mixture stirred overnight. The reaction was quenched with sat $\mathrm{NaHCO}_{3}(30 \mathrm{~mL})$ and a $10 \%$ aq solution of $\mathrm{Na}_{2} \mathrm{~S}_{2} \mathrm{O}_{3}(10 \mathrm{~mL})$. The aqueous phase was extracted with EtOAc and the combined organic phases were dried over $\mathrm{MgSO}_{4}$ and evaporated. $\mathrm{CC}$ (hexane/EtOAc 9:1) afforded nucleosides 7 (2,05 g, 85\%) as a yellowish solid.

Data for 7. $R_{f}=0.39($ hexane/EtOAc $4: 1) ;{ }^{1} \mathrm{H}$ NMR $\left(\mathrm{CDCl}_{3}, 300 \mathrm{MHz}\right) \delta 9.10(\mathrm{~s}, 1 \mathrm{H}, \mathrm{NH}), 7.76$ $(\mathrm{d}, J=0.9 \mathrm{~Hz}, 1 \mathrm{H}, \mathrm{H}-\mathrm{C}(6)), 6.38\left(\mathrm{~d}, J=2.6 \mathrm{~Hz}, 1 \mathrm{H}, \mathrm{H}-\mathrm{C}\left(1^{6}\right)\right), 4.56\left(\mathrm{~d}, J=2.6 \mathrm{~Hz}, 1 \mathrm{H}, \mathrm{H}-\mathrm{C}\left(2^{6}\right)\right)$, $4.19\left(\mathrm{~d}, J=5.7 \mathrm{~Hz}, 1 \mathrm{H}, \mathrm{H}-\mathrm{C}\left(4^{`}\right)\right), 2.45\left(\mathrm{~d}, J=14.2 \mathrm{~Hz}, 1 \mathrm{H}, \mathrm{H}_{\mathrm{b}}-\mathrm{C}\left(7^{`}\right)\right), 2.34\left(\mathrm{~m}, 1 \mathrm{H}, \mathrm{H}_{\mathrm{a}}-\mathrm{C}\left(7^{`}\right)\right)$, $1.91\left(\mathrm{~d}, J=0.9 \mathrm{~Hz}, 3 \mathrm{H}, \mathrm{CH}_{3}\right), 1.50\left(\mathrm{ddd}, J=2.2,7.8,20.9 \mathrm{~Hz}, 1 \mathrm{H}, \mathrm{H}_{\mathrm{b}}-\mathrm{C}\left(8^{\circ}\right)\right), 1.19(\mathrm{t}, J=8.4 \mathrm{~Hz}$, $\left.1 \mathrm{H}, \mathrm{H}_{\mathrm{a}}-\mathrm{C}\left(8^{\mathrm{c}}\right)\right), 0.94$ (s, 9H, $t$-Bu), 0.23 (s, 9H, TMS), 0.22, $0.20\left(2 \mathrm{~s}, 2 \mathrm{x} 3 \mathrm{H}, 2 \mathrm{xCH}_{3}\right) ;{ }^{13} \mathrm{C} \mathrm{NMR}$ $\left(\mathrm{CDCl}_{3}, 75 \mathrm{MHz}\right) \delta 164.3(\mathrm{~s}, \mathrm{CO}), 150.4(\mathrm{~s}, \mathrm{CO}), 135.4(\mathrm{~d}, \mathrm{C}(6)), 110.9(\mathrm{~s}, \mathrm{C}(5)), 96.8\left(\mathrm{~d}, \mathrm{C}\left(1^{\circ}\right)\right)$, 
$91.2\left(\mathrm{dd}, J(C, F)=3.7 \mathrm{~Hz}, \mathrm{C}\left(4^{\circ}\right)\right), 83.9\left(\mathrm{~d}, J(C, F)=11.4 \mathrm{~Hz}, \mathrm{C}\left(3^{\circ}\right)\right), 81.4(\mathrm{~d}, J(C, F)=250.9 \mathrm{~Hz}$, $\left.\mathrm{C}\left(6^{\circ}\right)\right), 62.7\left(\mathrm{~d}, J(C, F)=8.2 \mathrm{~Hz}, \mathrm{C}\left(5^{\circ}\right)\right), 41.5\left(\mathrm{~d}, \mathrm{C}\left(2^{\circ}\right)\right), 41.3\left(\mathrm{td}, J(C, F)=16.3 \mathrm{~Hz}, \mathrm{C}\left(7^{`}\right)\right), 25.7$ $(\mathrm{q}, t-\mathrm{Bu}), 21.7\left(\mathrm{td}, J(C, F)=10.2 \mathrm{~Hz}, \mathrm{C}-\left(8^{`}\right)\right), 18.0(\mathrm{~s}, t-\mathrm{Bu}), 12.4\left(\mathrm{q}, \mathrm{CH}_{3}\right), 2.1(\mathrm{q}, \mathrm{TMS}),-3.6(\mathrm{q}$, $\left.\mathrm{CH}_{3}\right),-4.0\left(\mathrm{q}, \mathrm{CH}_{3}\right) ;{ }^{19} \mathrm{~F} \mathrm{NMR}\left(\mathrm{CDCl}_{3}, 376 \mathrm{MHz}\right) \delta$-197.2 (m); ESI ${ }^{+}-\mathrm{HRMS} m / z$ calcd for $\mathrm{C}_{22} \mathrm{H}_{37} \mathrm{FIN}_{2} \mathrm{O}_{5} \mathrm{Si}_{2}[\mathrm{M}+\mathrm{H}]^{+}$611.1270, found 611.1265.

$\left(5^{6}-O\right.$-(tert-Butyldimethylsilyl)- $3^{6}-O$-(trimethylsilyl)-2 $2^{6}$-deoxy-36,56-ethano-6 6 -fluoro-5, $6^{6}-$ methano- $\boldsymbol{\beta}$-D-ribofuranosyl)thymine (8). To a solution of iodonucleoside 7 (2.05 $\mathrm{g}, 3.35$ $\mathrm{mmol})$ in toluene $(40 \mathrm{~mL})$ were added $\mathrm{Bu}_{3} \mathrm{SnH}(1.1 \mathrm{~mL}, 4.02 \mathrm{mmol})$ and azoisobutyronitril (AIBN, $165 \mathrm{mg}, 1.00 \mathrm{mmol}$ ) at $\mathrm{rt}$. After heating to reflux for $1 \mathrm{~h}$ the solvent was evaporated and the residue purified by $\mathrm{CC}$ (hexane/EtOAc $8: 2)$ to give nucleoside $\mathbf{8}(1,54 \mathrm{mg}, 95 \%$ ) as a colorless solid.

Data for 8. $R_{f}=0.52\left(\right.$ hexane/EtOAc 1:1); ${ }^{1} \mathrm{H}$ NMR $\left(\mathrm{CDCl}_{3}, 300 \mathrm{MHz}\right) \delta 8.52(\mathrm{~s}, 1 \mathrm{H}, \mathrm{NH}), 7.82$ $(\mathrm{d}, J=1.0 \mathrm{~Hz}, 1 \mathrm{H}, \mathrm{H}-\mathrm{C}(6)), 6.03\left(\mathrm{dd}, J=1.4,6.4 \mathrm{~Hz}, 1 \mathrm{H}, \mathrm{H}-\mathrm{C}\left(1^{\circ}\right)\right), 4.07(\mathrm{~d}, J=5.6 \mathrm{~Hz}, 1 \mathrm{H}, \mathrm{H}-$ $\left.\mathrm{C}\left(4^{\circ}\right)\right), 2.62\left(\mathrm{dd}, J=6.4,13.7 \mathrm{~Hz}, 1 \mathrm{H}, \mathrm{H}_{\mathrm{b}}-\mathrm{C}\left(2^{\circ}\right)\right), 2.53\left(\mathrm{dd}, J=1.4,13.7 \mathrm{~Hz}, 1 \mathrm{H}, \mathrm{H}_{\mathrm{a}^{-}} \mathrm{C}\left(2^{\circ}\right)\right), 2.37$ $\left(\mathrm{dd}, J=1.8,13.7 \mathrm{~Hz}, 1 \mathrm{H}, \mathrm{H}_{\mathrm{b}}-\mathrm{C}\left(7^{`}\right)\right), 2.13\left(\mathrm{~m}, 1 \mathrm{H}, \mathrm{H}_{\mathrm{a}}-\mathrm{C}\left(7^{`}\right)\right), 1.91\left(\mathrm{~d}, J=1.0 \mathrm{~Hz}, 3 \mathrm{H}, \mathrm{CH}_{3}\right), 1.40$ $\left(\mathrm{ddd}, J=2.4,7.7,21.0 \mathrm{~Hz}, 1 \mathrm{H}, \mathrm{H}_{\mathrm{b}}-\mathrm{C}\left(8^{\circ}\right)\right), 1.18\left(\mathrm{dd}, J=7.7,9.1 \mathrm{~Hz}, 1 \mathrm{H}, \mathrm{H}_{\mathrm{a}}-\mathrm{C}\left(8^{\circ}\right)\right), 0.94(\mathrm{~s}, 9 \mathrm{H}, t$ $\mathrm{Bu}), 0.23,0.19(2 \mathrm{~s}, 2 \mathrm{x} 3 \mathrm{H}, 2 \mathrm{xCH}), 0.13(\mathrm{~s}, 9 \mathrm{H}, \mathrm{TMS}) ;{ }^{13} \mathrm{C} \mathrm{NMR}\left(\mathrm{CDCl}_{3}, 75 \mathrm{MHz}\right) \delta 164.2(\mathrm{~s}$, CO), $150.2(\mathrm{~s}, \mathrm{CO}), 136.0(\mathrm{~d}, \mathrm{C}(6)), 110.2(\mathrm{~s}, \mathrm{C}(5)), 93.0\left(\mathrm{dd}, J(C, F)=4.0 \mathrm{~Hz}, \mathrm{C}\left(4^{\circ}\right)\right), 89.6(\mathrm{~d}$, $\left.\mathrm{C}\left(1^{\circ}\right)\right), 82.4\left(\mathrm{~d}, J(C, F)=12.3 \mathrm{~Hz}, \mathrm{C}\left(3^{\circ}\right)\right), 81.43\left(\mathrm{~d}, J(C, F)=249.7 \mathrm{~Hz}, \mathrm{C}\left(6^{\circ}\right)\right), 63.2(\mathrm{~d}, J(C, F)=$ $\left.8.1 \mathrm{~Hz}, \mathrm{C}\left(5^{\circ}\right)\right), 47.3\left(\mathrm{t}, \mathrm{C}\left(2^{`}\right)\right), 44.7\left(\mathrm{td}, J(C, F)=14.9 \mathrm{~Hz}, \mathrm{C}\left(7^{\circ}\right)\right), 25.7(\mathrm{q}, t-\mathrm{Bu}), 20.4(\mathrm{td}, J(C, F)$ $\left.=10.0 \mathrm{~Hz}, \mathrm{C}\left(8^{\circ}\right)\right), 18.0(\mathrm{~s}, t-\mathrm{Bu}), 12.3\left(\mathrm{q}, \mathrm{CH}_{3}\right), 2.0(\mathrm{q}, \mathrm{TMS}),-3.7\left(\mathrm{q}, \mathrm{CH}_{3}\right),-3.8\left(\mathrm{q}, \mathrm{CH}_{3}\right) ;{ }^{19} \mathrm{~F}$ 
NMR $\left(\mathrm{CDCl}_{3}, 376 \mathrm{MHz}\right) \delta$-197.9 (m); ESI+-HRMS $m / z$ calcd for $\mathrm{C}_{22} \mathrm{H}_{38} \mathrm{FN}_{2} \mathrm{O}_{5} \mathrm{Si}_{2}[\mathrm{M}+\mathrm{H}]^{+}$ 485.2303, found 485.2295.

\section{(2'-Deoxy- 3', $5^{6}$-ethano-6 ${ }^{6}$-fluoro-5', $6^{6}$-methano- $\beta$-D-ribofuranosyl)thymine (9). To}

a solution of compound $8(1.48 \mathrm{~g}, 3.05 \mathrm{mmol})$ and pyridine $(6 \mathrm{~mL})$ in $\mathrm{CH}_{2} \mathrm{Cl}_{2}(30 \mathrm{~mL})$ was added HF-pyridine $(1.5 \mathrm{~mL}, 60.6 \mathrm{mmol})$ at $0^{\circ} \mathrm{C}$. After stirring overnight at $\mathrm{rt}, \mathrm{SiO}_{2}(7 \mathrm{~g})$ was added and the mixture stirred for another $15 \mathrm{~min}$. After evaporation the adsorbed product was purified by CC (hexane/EtOAc/EtOH 5:5:1) to yield the title compound $\mathbf{9}(797 \mathrm{mg}, 87 \%)$ as a white foam.

Data for 9. $R_{f}=0.22(\mathrm{EtOAc}) ;{ }^{1} \mathrm{H} \mathrm{NMR}\left(\mathrm{CD}_{3} \mathrm{OD}, 400 \mathrm{MHz}\right) \delta 7.81(\mathrm{~d}, J=0.9 \mathrm{~Hz}, 1 \mathrm{H}, \mathrm{H}-\mathrm{C}(6))$, $6.13\left(\mathrm{dd}, J=4.0,6.9 \mathrm{~Hz}, 1 \mathrm{H}, \mathrm{H}-\mathrm{C}\left(1^{\circ}\right)\right), 3.99\left(\mathrm{~d}, J=5.7 \mathrm{~Hz}, 1 \mathrm{H}, \mathrm{H}-\mathrm{C}\left(4^{\circ}\right)\right), 2.56(\mathrm{dd}, J=6.9,13.9$ $\left.\mathrm{Hz}, 1 \mathrm{H}, \mathrm{H}_{\mathrm{b}}-\mathrm{C}\left(2^{\circ}\right)\right), 2.45\left(\mathrm{dd}, J=4.0,13.9 \mathrm{~Hz}, 1 \mathrm{H}, \mathrm{H}_{\mathrm{a}^{-}} \mathrm{C}\left(2^{\circ}\right)\right), 2.38\left(\mathrm{~m}, 2 \mathrm{H}, \mathrm{H}-\mathrm{C}\left(7^{\circ}\right)\right), 1.93(\mathrm{~d}, J=$ $\left.0.9 \mathrm{~Hz}, 3 \mathrm{H}, \mathrm{CH}_{3}\right), 1.43\left(\mathrm{ddd}, J=2.4,7.4,20.9 \mathrm{~Hz}, 1 \mathrm{H}, \mathrm{H}_{\mathrm{b}^{-}}\left(8^{\circ}\right)\right), 1.28\left(\mathrm{~m}, 1 \mathrm{H}, \mathrm{H}_{\mathrm{a}}-\mathrm{C}\left(8^{\circ}\right)\right) ;{ }^{13} \mathrm{C}$ NMR (CD $\left.{ }_{3} \mathrm{OD}, 100 \mathrm{MHz}\right) \delta 166.6$ (s, CO), 152.1 (s, CO), 137.7 (d, C(6)), 111.0 (s, C(5)), 91.5 $\left(\mathrm{dd}, J(C, F)=3.7 \mathrm{~Hz}, \mathrm{C}\left(4^{\circ}\right)\right), 89.0\left(\mathrm{~d}, \mathrm{C}\left(1^{\circ}\right)\right), 84.4\left(\mathrm{~d}, J(C, F)=248.0 \mathrm{~Hz}, \mathrm{C}\left(6^{\circ}\right)\right), 80.9(\mathrm{~d}, J(C, F)$ $\left.=12.1 \mathrm{~Hz}, \mathrm{C}\left(3^{\circ}\right)\right), 63.4\left(\mathrm{~d}, J(C, F)=8.4 \mathrm{~Hz}, \mathrm{C}\left(5^{\circ}\right)\right), 49.0\left(\mathrm{t}, \mathrm{C}\left(2^{\circ}\right)\right), 45.1(\mathrm{td}, J(C, F)=15.6 \mathrm{~Hz}$, $\left.\mathrm{C}\left(7^{\circ}\right)\right), 21.1\left(\mathrm{td}, J(C, F)=10.4 \mathrm{~Hz}, \mathrm{C}\left(8^{\circ}\right)\right), 12.4\left(\mathrm{q}, \mathrm{CH}_{3}\right) ;{ }^{19} \mathrm{~F} \mathrm{NMR}\left(\mathrm{CD}_{3} \mathrm{OD}, 376 \mathrm{MHz}\right) \delta-200.4$ (m); ESI ${ }^{+}-\mathrm{HRMS} m / z$ calcd for $\mathrm{C}_{13} \mathrm{H}_{16} \mathrm{FN}_{2} \mathrm{O}_{5}[\mathrm{M}+\mathrm{H}]^{+} 299.1038$, found 299.1037 .

\section{(5'-O-((4,4'-Dimethoxytriphenyl)methyl)-2'-deoxy-3 $3^{6}, 5^{6}$-ethano-6'-fluoro-5', $6^{6}$-methano- $\beta-$}

D-ribofuranosyl)thymine (10). To a solution of nucleoside $9(428 \mathrm{mg}, 1.44 \mathrm{mmol})$ in pyridine (20 $\mathrm{mL})$ was added DMTrCl (1,46 g, 4,31 mmol) at rt and the mixture was stirred for 2 days. Then reaction was diluted with sat. $\mathrm{NaHCO}_{3}$ and extraxted with EtOAc. The combined organic phasess were dried over $\mathrm{MgSO}_{4}$, evaporated and the residue purified by $\mathrm{CC}$ (hexane/EtOAc 8:2 
$\rightarrow$ EtOAc, $\left.1 \% \mathrm{Et}_{3} \mathrm{~N}\right)$ to give the title compound $\mathbf{1 0}(751 \mathrm{mg}, 87 \%)$ as a yellowish foam.

Data for 10. $R_{f}=0.38\left(\right.$ EtOAc); ${ }^{1} \mathrm{H} \mathrm{NMR}\left(\mathrm{CDCl}_{3}, 400 \mathrm{MHz}\right) \delta 9.62(\mathrm{brs}, 1 \mathrm{H}, \mathrm{NH}), 8.04(\mathrm{~d}, J=$ $0.8 \mathrm{~Hz}, 1 \mathrm{H}, \mathrm{H}-\mathrm{C}(6)), 7.47$ (m, 2H, H-arom), 7.37 (dd, J = 8.9, $10.7 \mathrm{~Hz}, 4 \mathrm{H}, \mathrm{H}$-arom), 7.16 (m, 3H, H-arom), 6.75 (dd, $J=7.6,8.9 \mathrm{~Hz}, 4 \mathrm{H}, \mathrm{H}$-arom), 5.76 (dd, $\left.J=1.4,6.5 \mathrm{~Hz}, 1 \mathrm{H}, \mathrm{H}-\mathrm{C}\left(1^{`}\right)\right), 3.70$ (s, 3H, OMe), 3.69 (s, 3H, OMe), $2.33\left(\mathrm{dd}, J=6.5,14.1 \mathrm{~Hz}, 1 \mathrm{H}, \mathrm{H}_{\mathrm{b}}-\left(2^{‘}\right)\right), 2.23\left(\mathrm{~m}, 3 \mathrm{H}, \mathrm{H}_{\mathrm{a}}-\mathrm{C}\left(2^{‘}\right)\right)$, $\left.\mathrm{H}-\mathrm{C}\left(4^{`}\right), \mathrm{H}_{\mathrm{b}}-\mathrm{C}\left(7^{`}\right)\right), 2.09\left(\mathrm{~m}, 1 \mathrm{H}, \mathrm{H}_{\mathrm{a}}-\mathrm{C}\left(7^{`}\right)\right), 1.98\left(\mathrm{~d}, J=0.8 \mathrm{~Hz}, 3 \mathrm{H}, \mathrm{CH}_{3}\right), 1.71\left(\mathrm{~m}, 1 \mathrm{H}, \mathrm{H}_{\mathrm{b}^{-}}\right.$ $\left.\mathrm{C}\left(8^{6}\right)\right), 0.84\left(\mathrm{dd}, J=8.6,9.7 \mathrm{~Hz}, 1 \mathrm{H}, \mathrm{H}_{\mathrm{a}}-\mathrm{C}\left(8^{6}\right)\right) ;{ }^{13} \mathrm{C} \mathrm{NMR}\left(\mathrm{CDCl}_{3}, 100 \mathrm{MHz}\right) \delta 164.7(\mathrm{~s}, \mathrm{CO})$, 158.95, 158.93 (2s, 2xC-arom), 150.5 (s, CO), 145.8, 136.5, 136.4 (3s, 3xC-arom), 136.3 (d, C6), 131.2, 131.1, 128.8, 127.8, 127.2, 113.13, 113.08 (7d, 7xC-arom), 110.3 (s, C(5)), 90.6 (dd, $J$ $\left.(C, F)=3.8 \mathrm{~Hz}, \mathrm{C}\left(4^{\circ}\right)\right), 88.82(\mathrm{~s}), 88.81\left(\mathrm{~d}, \mathrm{C}\left(1^{\circ}\right)\right), 83.3\left(\mathrm{~d}, J(C, F)=247.8 \mathrm{~Hz}, \mathrm{C}\left(6^{\circ}\right)\right), 80.5(\mathrm{~d}, J$ $\left.(C, F)=12.4 \mathrm{~Hz}, \mathrm{C}\left(3^{\circ}\right)\right), 64.9\left(\mathrm{~d}, J(C, F)=7.8 \mathrm{~Hz}, \mathrm{C}\left(5^{\circ}\right)\right), 55.4(\mathrm{q}, 2 \mathrm{xOMe}), 47.9\left(\mathrm{t}, \mathrm{C}\left(2^{\circ}\right)\right), 44.0$ $\left(\mathrm{td}, J(C, F)=16.0 \mathrm{~Hz}, \mathrm{C}\left(7^{\circ}\right)\right), 20.2\left(\mathrm{td}, J(C, F)=9.5 \mathrm{~Hz}, \mathrm{C}\left(8^{\circ}\right)\right), 12.5\left(\mathrm{q}, \mathrm{CH}_{3}\right) ;{ }^{19} \mathrm{~F} \mathrm{NMR}\left(\mathrm{CDCl}_{3}\right.$, $376 \mathrm{MHz}) \delta$-193.4 (m); ESI ${ }^{+}-\mathrm{HRMS} m / z$ calcd for $\mathrm{C}_{34} \mathrm{H}_{33} \mathrm{FN}_{2} \mathrm{O}_{7} \mathrm{Na}[\mathrm{M}+\mathrm{Na}]^{+}$623.2164, found 623.2150. 
(5'-O-(4,4'-Dimethoxytriphenyl)methyl)-3'-O-(2-cyanoethoxy)-

\section{diisopropylaminophosphanyl-2 ${ }^{6}$-deoxy-3 ${ }^{6}, 5^{6}$-ethano-6'-fluoro-5', $6^{6}$-methano- $\beta$-D-}

ribofuranosyl)thymine (11). To a solution of compound $10(4.24 \mathrm{~g}, 7.06 \mathrm{mmol})$ and diisopropylethylamine (4.67 ml, $28.24 \mathrm{mmol})$ in $\mathrm{CH}_{3} \mathrm{CN}(142 \mathrm{~mL}$ ) was added 2-cyanoethoxydiisopropylaminochlorophosphine $(3.94 \mathrm{~mL}, 17.65 \mathrm{mmol})$ at $\mathrm{rt}$. After stirring for $2 \mathrm{~h}$ at $\mathrm{rt}$, the mixture was diluted with EtOAc and washed with sat aq $\mathrm{NaHCO}_{3}$. The aqueous phases were extracted with EtOAc and the combined organic phases were dried $\left(\mathrm{MgSO}_{4}\right)$, evaporated and the resulting crude product purified by CC (hex/EtOAc $1: 1,1 \% \mathrm{NEt}_{3}$ ). The purified product was dissolved in $\mathrm{CH}_{2} \mathrm{Cl}_{2}(10 \mathrm{~mL})$, slowly added to icecold hexane $(220 \mathrm{~mL})$ and the precipitate collected. This procedure was repeated $7 \mathrm{x}$ to yield the pure title compound $\mathbf{1 1}(3,96 \mathrm{~g}, 70 \%)$ as a white amorphous solid.

Data for 11. $R_{f}=0.55\left(\right.$ EtOAc); ${ }^{1} \mathrm{H} \mathrm{NMR}\left(\mathrm{CDCl}_{3}, 400 \mathrm{MHz}\right) \delta 8.72$ (brs, $\left.1 \mathrm{H}, \mathrm{NH}\right), 8.01$ (dd, $J=$ 1.0, 5.6 Hz, 1H, H-C(6)), 7.48 (d, $J=8.1 \mathrm{~Hz}, \mathrm{H}$-arom, 2H,), 7.38 (t, $J=9.0 \mathrm{~Hz}, 4 \mathrm{H}, \mathrm{H}$-arom), 7.18 (m, 3H, H-arom), 6.75 (dd, $J=6.9,8.7 \mathrm{~Hz}, 4 \mathrm{H}, \mathrm{H}-\operatorname{arom}), 5.83(\mathrm{dd}, J=1.9,5.9 \mathrm{~Hz}, 1 \mathrm{H}, \mathrm{H}-$ $\left.\mathrm{C}\left(1^{\circ}\right)\right), 3.72(\mathrm{~m}, 6 \mathrm{H}, 2 \mathrm{xOMe}), 3.63\left(\mathrm{~m}, 1 \mathrm{H}, \mathrm{OCH}_{2}\right), 3.50\left(\mathrm{~m}, 1 \mathrm{H}, \mathrm{OCH}_{2}\right), 3.37(\mathrm{~m}, 2 \mathrm{H}, 2 \mathrm{x}$ $\left.\left.\left(\mathrm{Me}_{2} \mathrm{CH}\right) \mathrm{N}\right), 2.76\left(\mathrm{~m}, 1 \mathrm{H}, \mathrm{H}_{\mathrm{b}}-\mathrm{C}\left(7^{\circ}\right)\right), 2.62\left(\mathrm{~m}, 1 \mathrm{H}, \mathrm{H}_{\mathrm{b}}-\mathrm{C} 2^{\circ}\right)\right), 2.48\left(\mathrm{t}, J=6.3 \mathrm{~Hz}, 2 \mathrm{H}, \mathrm{CH}_{2} \mathrm{CN}\right)$, $2.32\left(\mathrm{~m}, 2 \mathrm{H}, \mathrm{H}_{\mathrm{a}}-\mathrm{C}\left(2^{\circ}\right), \mathrm{H}-\left(4^{\circ}\right)\right), 2.02\left(\mathrm{~m}, 1 \mathrm{H}, \mathrm{H}_{\mathrm{a}^{-}} \mathrm{C}\left(7^{\circ}\right)\right), 2.02\left(\mathrm{~s}, 3 \mathrm{H}, \mathrm{CH}_{3}\right), 1.72\left(\mathrm{~m}, 1 \mathrm{H}, \mathrm{H}_{\mathrm{b}^{-}}\right.$ $\left.\mathrm{C}\left(8^{\circ}\right)\right), 1.01\left(\mathrm{~m}, 12 \mathrm{H}, 2 \mathrm{x}\left(\mathrm{CH}_{3}\right)_{2} \mathrm{CHN}\right), 0.84\left(\mathrm{~m}, 1 \mathrm{H}, \mathrm{H}_{\mathrm{a}}-\mathrm{C}\left(8^{\circ}\right)\right) ;{ }^{13} \mathrm{C} \mathrm{NMR}\left(\mathrm{CDCl}_{3}, 100 \mathrm{MHz}\right) \delta$ 164.29, 164.26 (s, CO), 159.0 (m, 2xC-arom), 150.1 (s, CO), 145.8, 145.7 (s, C-arom), 136.5 (m, C-arom), 136.0 (d, C(6)), 131.2, 131.0, 128.8, 127.8, 127.3, 127.2, (6d, 6xC-arom), 117.6, 117.5 (2s, CN), 113.14, 113.10 (2d, 2xC-arom), 110.22, 110.19 (2s, C(5)), 91.3 (d, C(4‘)), 89.5, 89.3 $\left(2 \mathrm{~d}, \mathrm{C}\left(1^{\circ}\right)\right), 89.0,88.9(2 \mathrm{~s}), 83.8,83.7\left(2 \mathrm{~d}, J(C, F)=11.6 \mathrm{~Hz}\right.$ and $\left.12.4 \mathrm{~Hz} \mathrm{C}-\left(3^{\circ}\right)\right), 83.3,83.20$ $\left(2 \mathrm{~d}, J(C, F)=248.0, \mathrm{~Hz} \mathrm{C}\left(6^{\circ}\right)\right), 64.5\left(\mathrm{~m}, \mathrm{C}\left(5^{\circ}\right)\right), 58.0,57.7\left(2 \mathrm{td}, J(C, P)=19.5 \mathrm{~Hz}, \mathrm{OCH}_{2}\right), 55.4$, $55.3(2 \mathrm{q}, 2 \mathrm{xOMe}), 45.9,45.4\left(2 \mathrm{td}, J(C, P)=9.7 \mathrm{~Hz}\right.$ and $\left.12.9 \mathrm{~Hz}, \mathrm{C}\left(2^{\circ}\right)\right), 43.4,43.3(2 \mathrm{dd}, J(C, P)$ 
= 6.7 Hz, Me $2 \mathrm{CH}), 42.1\left(\mathrm{~m}, \mathrm{C}\left(7^{\circ}\right)\right), 24.50,24.45,24.42,24.37\left(4 \mathrm{q}, \mathrm{Me}_{2} \mathrm{CH}\right), 20.5,20.4$ (2td, $\left.\mathrm{CH}_{2} \mathrm{CN} J(C, P)=3.6 \mathrm{~Hz}, 4.1 \mathrm{~Hz}\right), 20.0\left(\mathrm{~m}, \mathrm{C}\left(8^{\circ}\right)\right), 12.5\left(\mathrm{q}, \mathrm{CH}_{3}\right) ;{ }^{19} \mathrm{~F} \mathrm{NMR}\left(\mathrm{CDCl}_{3}, 376 \mathrm{MHz}\right) \delta$ -193.8 (m), -193.6 (m); ${ }^{31} \mathrm{P}$ NMR ( $\left.\mathrm{CDCl}_{3}, 161 \mathrm{MHz}\right):$ 145.0, 142.9; $\mathrm{ESI}^{+}-\mathrm{HRMS} \mathrm{m} / \mathrm{z}$ calcd for $\mathrm{C}_{43} \mathrm{H}_{50} \mathrm{FN}_{4} \mathrm{O}_{8} \mathrm{PNa}[\mathrm{M}+\mathrm{Na}]^{+}$823.3243, found 823.3276.

(5'-O-(tert-Butyldimethylsilyl)- $3^{6}$ - $O$-(trimethylsilyl)-2 ${ }^{6}$-deoxy-3 ${ }^{6}, 5^{6}$-ethano-6 6 -fluoro-5 $5^{6}, 6^{6}-$ methano- $\beta$-D-ribofuranosyl)-4-(1H-1,2,4-triazol-1-yl)thymine (12). A suspension of 1,2,4triazol (19.81 g, $0.29 \mathrm{~mol})$ in $\mathrm{CH}_{3} \mathrm{CN}$ was cooled to $0^{\circ} \mathrm{C}$ and treated consecutively with $\mathrm{POCl}_{3}$ $(2.97 \mathrm{ml}, 31.87 \mathrm{mmol})$ and $\mathrm{Et}_{3} \mathrm{~N}(40.9 \mathrm{ml}, 293.25 \mathrm{mmol})$. The resulting mixture was stirred for 50 min before compound $\mathbf{8}(6.18 \mathrm{~g}, 12.75 \mathrm{mmol})$, dissolved in $\mathrm{CH}_{3} \mathrm{CN}(105 \mathrm{~mL})$, was added. After completion (TLC control, $3.5 \mathrm{~h}$ ) the reaction was quenched with sat aq $\mathrm{NaHCO}_{3}(200 \mathrm{~mL})$. The ice bath was removed and reduced to half of the volume in vacuo. Then EtOAc $(200 \mathrm{~mL})$ was added and the volume again reduced to one third. After pouring onto $\mathrm{H}_{2} \mathrm{O} / \mathrm{sat}$ aq $\mathrm{NaCl} 1: 1$, the resulting mixture was extracted with EtOAc. The combined organic phases were dried $\left(\mathrm{MgSO}_{4}\right)$ and evaporated. The crude compound $\mathbf{1 2}$ was used directly in the next step without further purification. For analytical data a sample was purified by CC (hexane/EtOAc 50:50). Data for 12. $R_{f}=0.35\left(\right.$ hexane/EtOAc 1:1); ${ }^{1} \mathrm{H}$ NMR $\left(\mathrm{CDCl}_{3}, 400 \mathrm{MHz}\right) \delta 9.28\left(\mathrm{~s}, 1 \mathrm{H}, \mathrm{H}-\mathrm{C}\left(5^{\prime \prime}\right)\right)$, $8.53(\mathrm{~s}, 1 \mathrm{H}, \mathrm{H}-\mathrm{C}(6)), 8.11$ (s, 1H, H-C(3’’)), 6.18 (t, $\left.J=3.9 \mathrm{~Hz}, 1 \mathrm{H}, \mathrm{H}-\mathrm{C}\left(1^{\circ}\right)\right), 4.18$ (d, $J=5.6 \mathrm{~Hz}$, 1H, H-C(4')), $2.76\left(\mathrm{~d}, J=3.9 \mathrm{~Hz}, 2 \mathrm{H}, \mathrm{H}-\mathrm{C}\left(2^{\circ}\right)\right), 2.45\left(\mathrm{~s}, 3 \mathrm{H}, \mathrm{CH}_{3}\right), 2.34(\mathrm{dd}, J=2.3,13.9 \mathrm{~Hz}$, $\left.1 \mathrm{H}, \mathrm{H}_{\mathrm{b}}-\mathrm{C}\left(7^{\circ}\right)\right), 1.85\left(\mathrm{~m}, 1 \mathrm{H}, \mathrm{H}_{\mathrm{a}-} \mathrm{C}\left(7^{\circ}\right)\right), 1.44\left(\mathrm{ddd}, J=2.3,7.7,21.0 \mathrm{~Hz}, 1 \mathrm{H}, \mathrm{H}_{\mathrm{b}}-\mathrm{C}\left(8^{\circ}\right)\right), 1.20$ (dd, $J$ = 7.7, $\left.9.1 \mathrm{~Hz}, 1 \mathrm{H}, \mathrm{H}_{\mathrm{a}-\mathrm{C}} \mathrm{C}\left(8^{\circ}\right)\right), 0.96(\mathrm{~s}, 9 \mathrm{H}, t-\mathrm{Bu}), 0.27,0.22\left(2 \mathrm{~s}, 2 \times 3 \mathrm{H}, 2 \mathrm{xCH}_{3}\right), 0.13(\mathrm{~s}, 9 \mathrm{H}, \mathrm{TMS})$; ${ }^{13} \mathrm{C} \mathrm{NMR}\left(\mathrm{CDCl}_{3}, 100 \mathrm{MHz}\right) \delta 158.6$ (s, C(4)), 154.0 (s, CO), 153.6 (d, C(3"))), 147.6 (d, C(6)), $145.2\left(\mathrm{~d}, \mathrm{C}\left(5^{\prime \prime}\right)\right), 106.0(\mathrm{~s}, \mathrm{C}(5)), 93.5\left(\mathrm{dd}, J(C, F)=3.9 \mathrm{~Hz}, \mathrm{C}\left(4^{\circ}\right)\right), 91.6\left(\mathrm{~d}, \mathrm{C}\left(1^{\circ}\right)\right), 82.3(\mathrm{~d}, J$ $\left.(C, F)=12.1 \mathrm{~Hz}, \mathrm{C}\left(3^{\circ}\right)\right), 81.3\left(\mathrm{~d}, J(C, F)=249.3 \mathrm{~Hz}, \mathrm{C}\left(6^{\circ}\right)\right), 63.3\left(\mathrm{~d}, J(C, F)=8.1 \mathrm{~Hz}, \mathrm{C}\left(5^{\circ}\right)\right)$, $46.4\left(\mathrm{t}, \mathrm{C}\left(2^{\circ}\right)\right), 45.0\left(\mathrm{td}, J(C, F)=14.7 \mathrm{~Hz}, \mathrm{C}\left(7^{\circ}\right)\right), 25.7(\mathrm{q}, t-\mathrm{Bu}), 20.2(\mathrm{td}, J(C, F)=10.0 \mathrm{~Hz}$, 
$\left.\mathrm{C}\left(8^{\circ}\right)\right), 18.0(\mathrm{~s}, t-\mathrm{Bu}), 16.9\left(\mathrm{q}, \mathrm{CH}_{3}\right), 2.0(\mathrm{q}, \mathrm{TMS}),-3.7\left(\mathrm{q}, \mathrm{CH}_{3}\right),-3.8\left(\mathrm{q}, \mathrm{CH}_{3}\right) ;{ }^{19} \mathrm{~F} \mathrm{NMR}\left(\mathrm{CDCl}_{3}\right.$, $376 \mathrm{MHz}) \delta-197.7(\mathrm{~m})$; ESI ${ }^{+}-\mathrm{HRMS} m / z$ calcd for $\mathrm{C}_{24} \mathrm{H}_{39} \mathrm{FN}_{5} \mathrm{O}_{4} \mathrm{Si}_{2}[\mathrm{M}+\mathrm{H}]^{+} 536.2519$, found 536.2503.

(5'-O-tert-Butyldimethylsilyl)-3'-O-(trimethylsilyl)-2'-deoxy-3', $5^{6}$-ethano-6'-fluoro-5',6'methano- $\beta$-D-ribofuranosyl)-5-methyl cytosine (13). To a solution of the crude compound 12 of the previous step $(10 \mathrm{~g})$, dissolved in 1,4-dioxane $(110 \mathrm{~mL})$, was added conc $\mathrm{NH}_{4} \mathrm{OH}(110$ $\mathrm{mL}$ ) and the mixture was stirred for $2 \mathrm{~h}$ at $\mathrm{rt}$. The solvent was evaporated and the residue dissolved in EtOAc and extracted with $\mathrm{H}_{2} \mathrm{O}$ and sat $\mathrm{NaCl}$. The aqueous phases were extracted with EtOAc and the combined organic layers dried $\left(\mathrm{MgSO}_{4}\right)$ and evaporated. The residue was purified by CC (EtOAc $\rightarrow$ EtOAc/EtOH 9:1) to yield the title compound $\mathbf{1 3}(3.70 \mathrm{~g}, 60 \%)$ as a white foam.

Data of 13. $R_{f}=0.48(\mathrm{EtOAc} / \mathrm{EtOH} 9: 1) ;{ }^{1} \mathrm{H} \mathrm{NMR}\left(\mathrm{CDCl}_{3}, 400 \mathrm{MHz}\right) \delta 7.92(\mathrm{~d}, J=0.7 \mathrm{~Hz}, 1 \mathrm{H}$, H-C(6)), $6.08\left(\mathrm{~m}, 1 \mathrm{H}, \mathrm{H}-\mathrm{C}\left(1^{\circ}\right)\right), 4.12\left(\mathrm{~m}, 1 \mathrm{H}, \mathrm{H}-\mathrm{C}\left(4^{\circ}\right)\right), 2.64\left(\mathrm{~d}, J=3.4 \mathrm{~Hz}, 2 \mathrm{H}, \mathrm{H}-\mathrm{C}\left(2^{\circ}\right)\right), 2.28$ $\left(\mathrm{dd}, J=2.0,13.7 \mathrm{~Hz}, 1 \mathrm{H}, \mathrm{H}_{\mathrm{b}}-\mathrm{C}\left(7^{\circ}\right)\right), 1.99\left(\mathrm{~m}, 1 \mathrm{H}, \mathrm{H}_{\mathrm{a}}-\mathrm{C}\left(7^{\circ}\right)\right), 1.94\left(\mathrm{~d}, J=0.7 \mathrm{~Hz}, 3 \mathrm{H}, \mathrm{CH}_{3}\right), 1.37$ (ddd, $\left.J=2.4,7.6,21.0 \mathrm{~Hz}, 1 \mathrm{H}, \mathrm{H}_{\mathrm{b}}-\mathrm{C}\left(8^{\circ}\right)\right), 1.17\left(\mathrm{dd}, J=7.6,9.1 \mathrm{~Hz}, 1 \mathrm{H}, \mathrm{H}_{\mathrm{a}}-\mathrm{C}\left(8^{\circ}\right)\right), 0.94(\mathrm{~s}, 9 \mathrm{H}, t-$ $\mathrm{Bu}), 0.24,0.19(2 \mathrm{~s}, 2 \mathrm{x} 3 \mathrm{H}, 2 \mathrm{xCH}), 0.10(\mathrm{~s}, 9 \mathrm{H}, \mathrm{TMS}) ;{ }^{13} \mathrm{C} \mathrm{NMR}\left(\mathrm{CDCl}_{3}, 100 \mathrm{MHz}\right) \delta 166.1(\mathrm{~s}$, C(4)), 156.3 (s, CO), 139.0 (d, C(6)), 101.6 (s, C(5)), 92.9 (dd, $J(C, F)=3.9$ Hz, C(4')), 90.3 (d, $\left.\mathrm{C}\left(1^{\circ}\right)\right), 82.3\left(\mathrm{~d}, J(C, F)=12.3 \mathrm{~Hz}, \mathrm{C}\left(3^{\circ}\right)\right), 81.5\left(\mathrm{~d}, J(C, F)=249.0 \mathrm{~Hz}, \mathrm{C}\left(6^{\circ}\right)\right), 63.3(\mathrm{~d}, J(C, F)=$ $\left.8.0 \mathrm{~Hz}, \mathrm{C}\left(5^{\circ}\right)\right), 46.9\left(\mathrm{t}, \mathrm{C}\left(2^{\circ}\right)\right), 44.7\left(\mathrm{td}, J(C, F)=14.7 \mathrm{~Hz}, \mathrm{C}\left(7^{\circ}\right)\right), 25.7(\mathrm{q}, t-\mathrm{Bu}), 20.2(\mathrm{td}, J(C, F)$ $\left.=9.9 \mathrm{~Hz}, \mathrm{C}\left(8^{\circ}\right)\right), 18.0(\mathrm{~s}, t-\mathrm{Bu}), 13.0\left(\mathrm{q}, \mathrm{CH}_{3}\right), 2.0(\mathrm{q}, \mathrm{TMS}),-3.7,-3.8\left(2 \mathrm{q}, 2 \mathrm{xCH}_{3}\right) ;{ }^{19} \mathrm{~F}$ NMR $\left(\mathrm{CDCl}_{3}, 376 \mathrm{MHz}\right) \delta-198.0(\mathrm{~m})$; $\mathrm{ESI}^{+}-\mathrm{HRMS} \mathrm{m} / z$ calcd for $\mathrm{C}_{22} \mathrm{H}_{39} \mathrm{FN}_{3} \mathrm{O}_{4} \mathrm{Si}_{2}[\mathrm{M}+\mathrm{H}]^{+} 484.2458$, found 484.2450 . 
$N^{4}$-Benzoyl-1-(5'-O-(tert-butyldimethylsilyl)-3'- $O$-(trimethylsilyl)-2'-deoxy-3 $3^{6}, 5^{6}$-ethano-6 ${ }^{6}-$

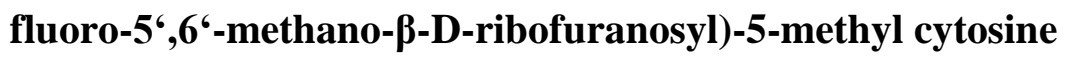
(14) and $N^{4}$-benzoyl-1-(5'-O(tert-butyldimethylsilyl)-2'-deoxy-3',5'-ethano-6'-fluoro-5', $6^{6}$-methano- $\beta$-D-ribofuranosyl)5-methyl cytosine (15). To a solution of nucleoside 13 (492 mg, $1.01 \mathrm{mmol}$ ) and DMAP (25 mg, $0.20 \mathrm{mmol})$ in $\mathrm{CH}_{3} \mathrm{CN}(20 \mathrm{~mL})$ was added $\mathrm{Bz}_{2} \mathrm{O}(253 \mathrm{mg}, 1.12 \mathrm{mmol})$ and the mixture was stirred for $1.5 \mathrm{~h}$ at $\mathrm{rt}$. Then $\mathrm{Et}_{3} \mathrm{~N}(0.28 \mathrm{ml}, 2.03 \mathrm{mmol})$ was added and the mixture stirred overnight. After evaporation of the solvents the residue was dissolved in EtOAc and washed with $\mathrm{H}_{2} \mathrm{O}$. The aqueous phase was extracted with EtOAc and the combined organic phases dried $\left(\mathrm{MgSO}_{4}\right)$ and evaporated. The crude product was purified by CC (hexane/EtOAc 95:5 $\rightarrow$ Hex:EtOAc 50:50) to give compound $\mathbf{1 4}(39 \%)$ as awhite foam and compound $\mathbf{1 5}(54 \%)$ as a white solid.

Data for 14. $R_{f}=0.62\left(\right.$ hexane/EtOAc 1:1); ${ }^{1} \mathrm{H} \mathrm{NMR}\left(\mathrm{CDCl}_{3}, 400 \mathrm{MHz}\right) \delta 13.46(\mathrm{~s}, 1 \mathrm{H}, \mathrm{NH})$, 8.32 (d, $J=7.3 \mathrm{~Hz}, 2 \mathrm{H}, \mathrm{H}$-arom), 8.03 (m, 1H, H-C(6)), 7.52 (m, 1H, H-arom), 7.44 (m, 2H, Harom), 6.09 (dd, $\left.J=1.1,6.5 \mathrm{~Hz}, 1 \mathrm{H}, \mathrm{H}-\mathrm{C}\left(1^{\circ}\right)\right), 4.11\left(\mathrm{~d}, J=5.6 \mathrm{~Hz}, 1 \mathrm{H}, \mathrm{H}-\mathrm{C}\left(4^{\circ}\right)\right), 2.67$ (dd, $J=$ 6.5, $\left.13.7 \mathrm{~Hz}, 1 \mathrm{H}, \mathrm{H}_{\mathrm{b}}-\mathrm{C}\left(2^{\circ}\right)\right), 2.60\left(\mathrm{dd}, J=1.1,13.7 \mathrm{~Hz}, 1 \mathrm{H}, \mathrm{H}_{\mathrm{a}}-\mathrm{C}\left(2^{\circ}\right)\right), 2.38(\mathrm{dd}, J=1.9,13.7 \mathrm{~Hz}$, $\left.1 \mathrm{H}, \mathrm{H}_{\mathrm{b}}-\mathrm{C}\left(7^{\circ}\right)\right), 2.12\left(\mathrm{~d}, J=0.9 \mathrm{~Hz}, 3 \mathrm{H}, \mathrm{CH}_{3}\right), 2.11\left(\mathrm{~m}, 1 \mathrm{H}, \mathrm{H}_{\mathrm{a}}-\mathrm{C}\left(7^{\circ}\right)\right), 1.43(\mathrm{ddd}, J=2.4,7.7,21.0$ $\left.\mathrm{Hz}, 1 \mathrm{H}, \mathrm{H}_{\mathrm{b}}-\mathrm{C}\left(8^{\circ}\right)\right), 1.20\left(\mathrm{dd}, J=7.7,9.0 \mathrm{~Hz}, 1 \mathrm{H}, \mathrm{H}_{\mathrm{a}}-\mathrm{C}\left(8^{\circ}\right)\right), 0.97(\mathrm{~s}, 9 \mathrm{H}, t-\mathrm{Bu}), 0.26,0.22(2 \mathrm{~s}$,

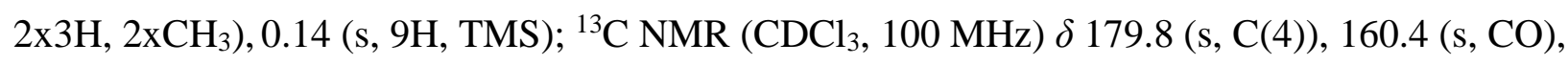
147.9 (s, CO), 137.49 (s, C-arom), 137.45 (d, C(6)), 132.4, 130.0, 128.2 (3d, 3xC-arom), 111.4 (s, C(5)), $93.2\left(\mathrm{dd}, J(C, F)=4.0 \mathrm{~Hz}, \mathrm{C}\left(4^{\circ}\right)\right), 90.1\left(\mathrm{~d}, \mathrm{C}\left(1^{\circ}\right)\right), 82.3\left(\mathrm{~d}, J(C, F)=12.3 \mathrm{~Hz}, \mathrm{C}\left(3^{\circ}\right)\right)$, $81.4\left(\mathrm{~d}, J(C, F)=249.5 \mathrm{~Hz}, \mathrm{C}\left(6^{\circ}\right)\right), 63.2\left(\mathrm{~d}, J(C, F)=8.1 \mathrm{~Hz}, \mathrm{C}\left(5^{\circ}\right)\right), 47.1\left(\mathrm{t}, \mathrm{C}\left(2^{\circ}\right)\right), 44.8(\mathrm{td}, J$ $\left.(C, F)=14.9 \mathrm{~Hz}, \mathrm{C}\left(7^{\circ}\right)\right), 25.7(\mathrm{q}, t-\mathrm{Bu}), 20.3\left(\mathrm{td}, J(C, F)=10.1 \mathrm{~Hz}, \mathrm{C}\left(8^{\circ}\right)\right), 18.0(\mathrm{~s}, t-\mathrm{Bu}), 13.4(\mathrm{q}$, $\left.\mathrm{CH}_{3}\right), 2.0$ (q, TMS), -3.7 (q, $\left.\mathrm{CH}_{3}\right),-3.8\left(\mathrm{q}, \mathrm{CH}_{3}\right) ;{ }^{19} \mathrm{~F} \mathrm{NMR}\left(\mathrm{CDCl}_{3}, 376 \mathrm{MHz}\right) \delta-197.9(\mathrm{~m})$; 
ESI ${ }^{+}-\mathrm{HRMS} m / z$ calcd for $\mathrm{C}_{29} \mathrm{H}_{43} \mathrm{FN}_{3} \mathrm{O}_{5} \mathrm{Si}_{2}[\mathrm{M}+\mathrm{H}]^{+}$588.2720, found 588.2714.

Data for 15. $R_{f}=0.30\left(\right.$ hexane/EtOAc 1:1); ${ }^{1} \mathrm{H} \mathrm{NMR}\left(\mathrm{CDCl}_{3}, 400 \mathrm{MHz}\right) \delta 8.29(\mathrm{~m}, 2 \mathrm{H}, \mathrm{H}$-arom $)$, 8.07 (d, $J=0.8 \mathrm{~Hz}, 1 \mathrm{H}, \mathrm{H}-\mathrm{C}(6)), 7.48$ (m, 4H, H-arom, NH), 6.09 (dd, $J=2.3,5.6 \mathrm{~Hz}, 1 \mathrm{H}, \mathrm{H}-$ $\left.\mathrm{C}\left(1^{\circ}\right)\right), 4.13\left(\mathrm{~d}, J=5.5 \mathrm{~Hz}, 1 \mathrm{H}, \mathrm{H}-\mathrm{C}\left(4^{`}\right)\right), 2.64\left(\mathrm{~m}, 2 \mathrm{H}, \mathrm{H}-\mathrm{C}\left(2^{\circ}\right)\right), 2.35(\mathrm{dd}, J=1.6,13.9 \mathrm{~Hz}, 1 \mathrm{H}$, $\left.\mathrm{H}_{\mathrm{b}}-\mathrm{C}\left(7^{\circ}\right)\right), 2.20\left(\mathrm{~m}, 1 \mathrm{H}, \mathrm{H}_{\mathrm{a}}-\mathrm{C}\left(7^{\circ}\right)\right), 2.12\left(\mathrm{~d}, J=0.8 \mathrm{~Hz}, 3 \mathrm{H}, \mathrm{CH}_{3}\right), 1.46(\mathrm{ddd}, J=2.4,7.8,21.0 \mathrm{~Hz}$, $\left.1 \mathrm{H}, \mathrm{H}_{\mathrm{b}}-\mathrm{C}\left(8^{\circ}\right)\right), 1.28\left(\mathrm{~m}, 1 \mathrm{H}, \mathrm{H}_{\mathrm{a}}-\mathrm{C}\left(8^{\circ}\right)\right), 0.97(\mathrm{~s}, 9 \mathrm{H}, t-\mathrm{Bu}), 0.25,0.21\left(2 \mathrm{~s}, 2 \mathrm{x} 3 \mathrm{H}, 2 \mathrm{xCH}_{3}\right) ;{ }^{13} \mathrm{C}$ NMR ( $\left.\mathrm{CDCl}_{3}, 100 \mathrm{MHz}\right) \delta 179.4$ (s, C(4)), 160.5 (s, CO), 148.2 (s, CO), 137.9 (d, C(6)), 137.2 (s, C-arom), 132.6, 123.0, 128.3 (3d, 3xC-arom), 111.5 (s, C(5)), 91.8 (dd, $J(C, F)=3.8 \mathrm{~Hz}$, $\left.\mathrm{C}\left(4^{\circ}\right)\right), 90.0\left(\mathrm{~d}, \mathrm{C}\left(1^{\circ}\right)\right), 81.5\left(\mathrm{~d}, J(C, F)=249.1 \mathrm{~Hz}, \mathrm{C}\left(6^{\circ}\right)\right), 80.7\left(\mathrm{~d}, J(C, F)=12.0 \mathrm{~Hz}, \mathrm{C}\left(3^{\circ}\right)\right)$, $63.5\left(\mathrm{~d}, J(C, F)=8.2 \mathrm{~Hz}, \mathrm{C}\left(5^{\circ}\right)\right), 47.9\left(\mathrm{t}, \mathrm{C}\left(2^{\circ}\right)\right), 44.8\left(\mathrm{td}, J(C, F)=15.8 \mathrm{~Hz}, \mathrm{C}\left(7^{\circ}\right)\right), 25.7(\mathrm{q}, t-$ $\mathrm{Bu}), 20.5\left(\mathrm{td}, J(C, F)=10.1 \mathrm{~Hz}, \mathrm{C}\left(8^{\circ}\right)\right), 18.0(\mathrm{~s}, t-\mathrm{Bu}), 13.4\left(\mathrm{q}, \mathrm{CH}_{3}\right),-3.7\left(\mathrm{q}, \mathrm{CH}_{3}\right),-3.8\left(\mathrm{q}, \mathrm{CH}_{3}\right)$; ${ }^{19} \mathrm{~F} \mathrm{NMR}\left(\mathrm{CDCl}_{3}, 376 \mathrm{MHz}\right) \delta$-197.6 (m); ESI ${ }^{+}$-HRMS m/z calcd for $\mathrm{C}_{26} \mathrm{H}_{35} \mathrm{FN}_{3} \mathrm{O}_{5} \mathrm{Si}[\mathrm{M}+\mathrm{H}]^{+}$ 516.2325, found 516.2328.

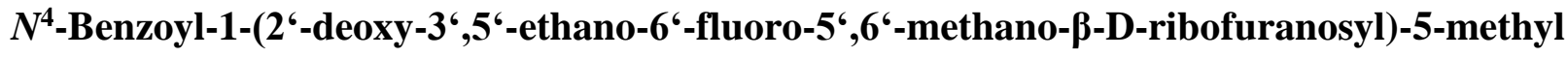

cytosine (16). To separate solutions of nucleoside 14 and 15 (1.85 g, 3.15 mmol and 1.24 g, 2.41 mmol resp.) and pyridine (9.6 mL and $6.0 \mathrm{~mL}$, resp.) in $\mathrm{CH}_{2} \mathrm{Cl}_{2}(40 \mathrm{~mL}$ and $30 \mathrm{~mL}$, resp.) was added HF-pyridine $\left(3.3 \mathrm{~mL}\right.$ and $2.1 \mathrm{~mL}$, resp.) at $0^{\circ} \mathrm{C}$. After stirring for $24 \mathrm{~h}$ at $\mathrm{rt}$, silica gel $(1 \mathrm{~g}$ per $300 \mathrm{mg}$ starting material) was added and the mixtures stirred for another $15 \mathrm{~min}$. After evaporation the adsorbed products were purified by $\mathrm{CC}$ (EtOAc) to give the title compound $\mathbf{1 6}$ $(1,13 \mathrm{~g}$ from $\mathbf{1 4}, 867 \mathrm{mg}$ from $\mathbf{1 5}, 90 \%$ together) as white foams.

Data for 16. $R_{f}=0.48(\mathrm{EtOAc}) ;{ }^{1} \mathrm{H} \mathrm{NMR}\left(\mathrm{CD}_{3} \mathrm{OD}, 400 \mathrm{MHz}\right) \delta 8.23(\mathrm{~m}, 2 \mathrm{H}, \mathrm{H}$-arom $), 8.11(\mathrm{~m}$, 1H, H-C(6)), 7.58 (m, 1H, H-arom), 7.47 (m, 2H, H-arom), 6.15 (dd, J=3.1, 7.0 Hz, 1H, H$\left.\mathrm{C}\left(1^{\circ}\right)\right), 4.08\left(\mathrm{~d}, J=5.6 \mathrm{~Hz}, 1 \mathrm{H}, \mathrm{H}-\mathrm{C}\left(4^{\circ}\right)\right), 2.65\left(\mathrm{dd}, J=7.0,14.0 \mathrm{~Hz}, 1 \mathrm{H}, \mathrm{H}_{\mathrm{b}^{-}}\left(2^{`}\right)\right), 2.53(\mathrm{dd}, J=$ 
3.1, $\left.14.0 \mathrm{~Hz}, 1 \mathrm{H}, \mathrm{H}_{\mathrm{a}-\mathrm{C}} \mathrm{C}\left(2^{\circ}\right)\right), 2.32\left(\mathrm{~m}, 2 \mathrm{H}, \mathrm{H}-\mathrm{C}\left(7^{\circ}\right)\right), 2.14\left(\mathrm{~d}, 3 \mathrm{H}, J=0.9 \mathrm{~Hz}, \mathrm{CH}_{3}\right), 1.45(\mathrm{dd}, J=$ 7.5, 20.9 Hz, 1H, $\left.\mathrm{H}_{\mathrm{b}}-\mathrm{C}\left(8^{\circ}\right)\right), 1.31\left(\mathrm{t}, J=7.5 \mathrm{~Hz}, 1 \mathrm{H}, \mathrm{H}_{\mathrm{a}}-\mathrm{C}\left(8^{\circ}\right)\right) ;{ }^{13} \mathrm{C} \mathrm{NMR}\left(\mathrm{CD}_{3} \mathrm{OD}, 75 \mathrm{MHz}\right) \delta$ 162.1 (s, C(4)), 148.0 (s, CO), 143.4 (s, CO), 137.7 (d, C(6)), 137.6 (s, C-arom), 133.6, 130.5, 129.3 (3d, 3xC-arom), 112.0 (s, C(5)), $91.9\left(\mathrm{dd}, J(C, F)=3.7 \mathrm{~Hz}, \mathrm{C}\left(4^{\circ}\right)\right), 90.2\left(\mathrm{~d}, \mathrm{C}\left(1^{\circ}\right)\right), 84.3(\mathrm{~d}$, $\left.J(C, F)=248.1 \mathrm{~Hz}, \mathrm{C}\left(6^{\circ}\right)\right), 80.8\left(\mathrm{~d}, J(C, F)=12.0 \mathrm{~Hz}, \mathrm{C}\left(3^{\circ}\right)\right), 63.4\left(\mathrm{~d}, J(C, F)=8.5 \mathrm{~Hz}, \mathrm{C}\left(5^{\circ}\right)\right)$, $48.2\left(\mathrm{t}, \mathrm{C}\left(2^{\circ}\right)\right), 45.2\left(\mathrm{td}, J(C, F)=15.5 \mathrm{~Hz}, \mathrm{C}\left(7^{\circ}\right)\right), 21.1\left(\mathrm{td}, J(C, F)=10.3 \mathrm{~Hz}, \mathrm{C}\left(8^{\circ}\right)\right), 13.8(\mathrm{q}$, $\left.\mathrm{CH}_{3}\right) ;{ }^{19} \mathrm{~F}$ NMR $\left(\mathrm{CD}_{3} \mathrm{OD}, 376 \mathrm{MHz}\right) \delta-200.4(\mathrm{~m}) ; \mathrm{ESI}^{+}-\mathrm{HRMS} m / z$ calcd for $\mathrm{C}_{20} \mathrm{H}_{21} \mathrm{FN}_{3} \mathrm{O}_{5}$ $[\mathrm{M}+\mathrm{H}]^{+}$402.1460, found 402.1461 .

$N^{4}$-Benzoyl-1-(5'-O-((4,4'dimethoxytriphenyl)methyl)-2 ${ }^{6}$-deoxy-3' ${ }^{6}, 5^{6}$-ethano-6 ${ }^{6}$-fluoro-5 ${ }^{6}, 6^{6}-$

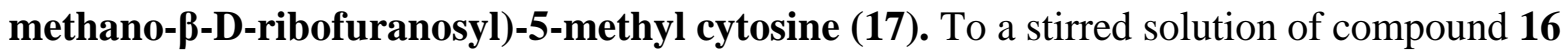
(606 mg, $1.51 \mathrm{mmol})$ in pyridine $(20 \mathrm{~mL})$ was added $\mathrm{DMTrCl}(1.54 \mathrm{~g}, 4.53 \mathrm{mmol})$ at rt. After 2 days the mixture was poured onto sat aq $\mathrm{NaHCO}_{3}$ and extraxted with EtOAc. The combined organic layers were dried $\left(\mathrm{MgSO}_{4}\right)$, evaporated and the crude material purified by $\mathrm{CC}$ (hexane/EtOAc $8: 2 \rightarrow 6: 4,+0,2 \% \mathrm{Et}_{3} \mathrm{~N}$ ) to give the title compound $\mathbf{1 7}(843 \mathrm{mg}, 79 \%)$ as a yellowish foam.

Data for 17. $R_{f}=0.44\left(\right.$ hexane/EtOAc 1:3); ${ }^{1} \mathrm{H}$ NMR $\left(\mathrm{CDCl}_{3}, 400 \mathrm{MHz}\right) \delta 13.37$ (brs, $\left.1 \mathrm{H}, \mathrm{NH}\right)$, 8.26 (m, 2H, H-arom, H-C(6)), 7.42 (m, 9H, H-arom), 7.20 (m, 4H, H-arom), 6.77 (dd, J = 7.6, $9.0 \mathrm{~Hz}, 4 \mathrm{H}, \mathrm{H}$-arom), 5.85 (dd, $\left.J=1.5,6.4 \mathrm{~Hz}, 1 \mathrm{H}, \mathrm{H}-\mathrm{C}\left(1^{\circ}\right)\right), 3.73$ (s, 3H, OMe), 3.72 (s, 3H, OMe), $2.39\left(\mathrm{dd}, J=1.5,14.1 \mathrm{~Hz}, 1 \mathrm{H}, \mathrm{H}_{\mathrm{b}}-\mathrm{C}\left(2^{6}\right)\right), 2.33\left(\mathrm{dd}, J=6.4,14.1 \mathrm{~Hz}, 1 \mathrm{H}, \mathrm{H}_{\mathrm{a}}-\mathrm{C}\left(2^{6}\right)\right), 2.22$ $\left(\mathrm{d}, J=0.7 \mathrm{~Hz}, 3 \mathrm{H}, \mathrm{CH}_{3}\right), 2.21\left(\mathrm{~m}, 2 \mathrm{H}, \mathrm{H}-\mathrm{C}\left(4^{\circ}\right), \mathrm{H}_{\mathrm{b}}-\mathrm{C}\left(7^{\circ}\right)\right), 2.11\left(\mathrm{~m}, 1 \mathrm{H}, \mathrm{H}_{\mathrm{a}}-\mathrm{C}\left(7^{\circ}\right)\right), 1.77(\mathrm{ddd}, J=$ 2.1, 8.3, 20.4 Hz, $\left.1 \mathrm{H}, \mathrm{H}_{\mathrm{b}} \mathrm{C}\left(8^{\circ}\right)\right), 1.56$ (brs, $\left.1 \mathrm{H}, \mathrm{OH}\right), 0.85\left(\mathrm{dd}, J=8.3,9.6 \mathrm{~Hz}, 1 \mathrm{H}, \mathrm{H}_{\mathrm{a}}-\mathrm{C}\left(8^{\circ}\right)\right) ;{ }^{13} \mathrm{C}$ NMR (CDCl $3,100 \mathrm{MHz}) \delta 181.3$ (s, C(4)), 160.4 (s, CO), 159.08, 159.06 (2s, 2xC-arom), 147.9 (s, CO), 145.9 (s, C-arom), 137.5 (d, C(6)), 137.4, 136.44, 136.37 (3s, 3xC-arom), 132.6, 131.2, 
131.1, 130.0, 128.9, 128.3, 127.9, 127.4, 113.19, 113.15 (10d, 10xC-arom), 111.1 (s, C(5)), 90.9 $\left(\mathrm{dd}, J(C, F)=4.1 \mathrm{~Hz}, \mathrm{C}\left(4^{\circ}\right)\right), 89.4\left(\mathrm{~d}, \mathrm{C}\left(1^{\circ}\right)\right), 89.0(\mathrm{~s}), 83.2\left(\mathrm{~d}, J(C, F)=248.1 \mathrm{~Hz}, \mathrm{C}\left(6^{\circ}\right)\right), 80.8$ $\left(\mathrm{d}, J(C, F)=12.2 \mathrm{~Hz}, \mathrm{C}\left(3^{\circ}\right)\right), 64.9\left(\mathrm{~d}, J(C, F)=7.9 \mathrm{~Hz}, \mathrm{C}\left(5^{\circ}\right)\right), 55.4(\mathrm{q}, 2 \mathrm{xOMe}), 47.9\left(\mathrm{t}, \mathrm{C}\left(2^{\circ}\right)\right)$, $44.2\left(\operatorname{td}, J(C, F)=16.2 \mathrm{~Hz}, \mathrm{C}\left(7^{\circ}\right)\right), 20.2\left(\operatorname{td}, J(C, F)=9.7 \mathrm{~Hz}, \mathrm{C}\left(8^{\circ}\right)\right), 13.6\left(\mathrm{q}, \mathrm{CH}_{3}\right) ;{ }^{19} \mathrm{~F}$ NMR $\left(\mathrm{CDCl}_{3}, 376 \mathrm{MHz}\right) \delta-193.5(\mathrm{~m}) ; \mathrm{ESI}^{+}-\mathrm{HRMS} \mathrm{m} / z$ calcd for $\mathrm{C}_{41} \mathrm{H}_{39} \mathrm{FN}_{3} \mathrm{O}_{7}[\mathrm{M}+\mathrm{H}]^{+}$704.2767, found 704.2771.

\section{$N^{4}$-Benzoyl-1-(5'-O-((4,46-dimethoxytriphenyl)methyl)- $3^{6} O$-(2-cyanoethoxy)-}

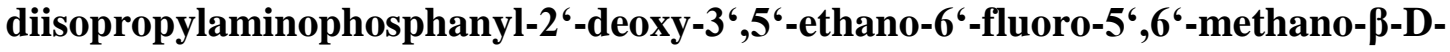

ribofuranosyl)-5-methyl cytosine (18). To a solution of compound $17(2.37 \mathrm{~g}, 3.37 \mathrm{mmol})$ and diisopropylethylamine (2.23 $\mathrm{mL}, 13,47 \mathrm{mmol})$ in $\mathrm{CH}_{3} \mathrm{CN}(50 \mathrm{~mL})$ was added 2-cyanoethoxydiisopropylaminochlorophosphine $(1.88 \mathrm{~mL}, 8.42 \mathrm{mmol})$. After stirring for $2 \mathrm{~h}$ at $\mathrm{rt}$, the mixture was diluted with EtOAc and washed with sat aq $\mathrm{NaHCO}_{3}$. The aqueous phases were extracted with EtOAc and the combined organic phases dried $\left(\mathrm{MgSO}_{4}\right)$, evaporated and the crude product purified by CC (hexane/EtOAc 1:1, +1\% NEt 3 ) to give the title compound $\mathbf{1 8}(2.78 \mathrm{~g}, 90 \%)$ as a yellowish foam.

Data for 18. $R_{f}=0.71\left(\right.$ hexane/EtOAc 1:3); ${ }^{1} \mathrm{H}$ NMR $\left(\mathrm{CDCl}_{3}, 400 \mathrm{MHz}\right) \delta 13.39$ (brs, $\left.1 \mathrm{H}, \mathrm{NH}\right)$, 8.25 (m, 3H, H-arom, H-C(6)), 7.43 (m, 9H, H-arom), 7.18 (m, 3H, H-arom), 6.76 (m, 4H, Harom), $5.88\left(\mathrm{~d}, J=6.8 \mathrm{~Hz}, 1 \mathrm{H}, \mathrm{H}-\mathrm{C}\left(1^{\circ}\right)\right), 3.72(\mathrm{~m}, 6 \mathrm{H}, 2 \mathrm{xOMe}), 3.62\left(\mathrm{~m}, 1 \mathrm{H}, \mathrm{OCH}_{2}\right), 3.49(\mathrm{~m}$, 1H, $\left.\mathrm{OCH}_{2}\right), 3.36\left(\mathrm{~m}, 2 \mathrm{H}, 2 \mathrm{x}\left(\mathrm{Me}_{2} \mathrm{CH}\right) \mathrm{N}\right), 2.76\left(\mathrm{~m}, 1 \mathrm{H}, \mathrm{H}_{\mathrm{b}} \mathrm{C}\left(7^{\circ}\right)\right), 2.62\left(\mathrm{~m}, 2 \mathrm{H}, \mathrm{H}-\mathrm{C}\left(2^{\circ}\right)\right), 2.47$ (m, $\left.2 \mathrm{H}, \mathrm{CH}_{2} \mathrm{CN}\right), 2.36\left(\mathrm{~m}, 1 \mathrm{H}, \mathrm{H}-\mathrm{C}\left(4^{\circ}\right)\right), 2.21\left(\mathrm{~s}, 3 \mathrm{H}, \mathrm{CH}_{3}\right), 2.01\left(\mathrm{~m}, 1 \mathrm{H}, \mathrm{H}_{\mathrm{a}}-\mathrm{C}\left(7^{\circ}\right)\right), 1.74(\mathrm{~m}, 1 \mathrm{H}$, $\left.\mathrm{H}_{\mathrm{b}}-\mathrm{C}\left(8^{\circ}\right)\right), 1.01\left(\mathrm{~m}, 12 \mathrm{H}, 2 \mathrm{x}\left(\mathrm{CH}_{3}\right)_{2} \mathrm{CHN}\right), 0.85\left(\mathrm{~m}, 1 \mathrm{H}, \mathrm{H}_{\mathrm{a}}-\mathrm{C}\left(8^{\circ}\right)\right) ;{ }^{13} \mathrm{C} \mathrm{NMR}\left(\mathrm{CDCl}_{3}, 100 \mathrm{MHz}\right) \delta$ 179.7 (s, C(4)), 160.4 (s, CO), 159.1, 159.04, 159.02, 159.01 (4s, 4xC-arom), 147.8 (s, CO), 145.70, 145.65 (2s, C-arom), 137.4 (d, C(6)), 136.43, 136.39136 .32 (3s, 3xC-arom), 132.4, 
131.2, 131.0, 130.0, 128.8, 128.2, 127.9, 127.3, 127.2, (9d, 9xC-arom), 117.5, 117.4 (2s, CN),

113.2, 113.1 (2d, 2xC-arom), 111.31, 111.27 (2s, C(5)), 91.5 (md, C(4')), 90.0, 89.9 (2d, $\left.\mathrm{C}\left(1^{\circ}\right)\right)$,

89.03, $88.98(2 \mathrm{~s}), 83.7\left(\mathrm{~m}, \mathrm{C}\left(3^{\circ}\right)\right), 83.3,83.2\left(2 \mathrm{~d}, J(C, F)=248.6 \mathrm{~Hz}, \mathrm{C}\left(6^{\circ}\right)\right), 64.63,64.55(2 \mathrm{~d}, J$

$\left.(C, F)=3.6 \mathrm{~Hz}, \mathrm{C}\left(5^{\circ}\right)\right), 58.0,57.7\left(2 \mathrm{td}, J(C, P)=19.4 \mathrm{~Hz}, \mathrm{OCH}_{2}\right), 55.34,55.30(2 \mathrm{q}, 2 \mathrm{xOMe})$,

45.7, $45.2\left(2 \mathrm{td}, J(C, P)=9.7,12.9 \mathrm{~Hz}, \mathrm{C}\left(2^{`}\right)\right), 43.4,43.3\left(2 \mathrm{dd}, J(C, P)=12.6 \mathrm{~Hz}, 2 \mathrm{xMe}_{2} \mathrm{CH}\right)$,

42.2, $42.1\left(2 \mathrm{td}, J(C, F) J(C, P)=10.5,12.3 \mathrm{~Hz}, \mathrm{C}\left(7^{\circ}\right)\right), 24.53,24.47,24.40,24.35(4 \mathrm{q}$,

$2 \mathrm{xMe} 2 \mathrm{CH}), 20.4,20.3\left(2 \mathrm{td} J(C, P)=2.0,2.7 \mathrm{~Hz}, \mathrm{CH}_{2} \mathrm{CN}\right), 20.0,19.9(2 \mathrm{td}, J(C, F)=10.2 \mathrm{~Hz}$,

$\left.\mathrm{C}\left(8^{\circ}\right)\right), 13.5\left(\mathrm{q}, \mathrm{CH}_{3}\right) ;{ }^{19} \mathrm{~F} \mathrm{NMR}\left(\mathrm{CDCl}_{3}, 376 \mathrm{MHz}\right) \delta-193.7(\mathrm{~m}),-193.5(\mathrm{~m}) ;{ }^{31} \mathrm{P} \mathrm{NMR}\left(\mathrm{CDCl}_{3}\right.$,

$161 \mathrm{MHz}) d$ 145.1, 143.0; $\mathrm{ESI}^{+}-\mathrm{HRMS} m / z$ calcd for $\mathrm{C}_{50} \mathrm{H}_{56} \mathrm{FN}_{5} \mathrm{O}_{8} \mathrm{P}[\mathrm{M}+\mathrm{H}]^{+}$904.3845, found 904.3846.

Oligonucleotide synthesis and purification. Oligonucleotides ON1-10 were synthesized by standard solid phase phosphoramidite methodology on the $1.3 \mu \mathrm{mol}$ scale on a Pharmacia LKB Gene Assembler Special DNA Synthesizer using a slightly modified DNA synthesis program. Natural phosphoramidites ( $\mathrm{dT}, \mathrm{dC}^{4} \mathrm{Bz}, \mathrm{dA}^{6} \mathrm{Bz}, \mathrm{dG}^{2} \mathrm{dmf}$ ) were coupled as a $0.1 \mathrm{M}$ solution in $\mathrm{CH}_{3} \mathrm{CN}$, tricyclophosphoramidites as $0.15 \mathrm{M}$ solutions in $\mathrm{CH}_{3} \mathrm{CN}$ with the exception of 6'F-tc- $\mathrm{T}$, 6 ' F-tc- ${ }^{5 \mathrm{Me}} \mathrm{C}^{4} \mathrm{Bz}$ and tc-A that were used as $0.15 \mathrm{M}$ solutions in DCE. The coupling step was $90 \mathrm{~s}$ for natural phosphoramidites and $12 \mathrm{~min}$ for tricyclo-phosphoramidites. As coupling reagent, 5(ethylthio)-1H-tetrazole ( $0.25 \mathrm{M}$ in $\left.\mathrm{CH}_{3} \mathrm{CN}\right)$ was used. Capping, oxidation and detritylation were carried out using standard solutions as described in the manufacturer's protocol. Deprotection of the oligonucleotides after assembly and detachment from solid support was effected by standard ammonia treatment $\left(33 \%\right.$ aq $\left.\mathrm{NH}_{3}, 16 \mathrm{~h}, 55^{\circ} \mathrm{C}\right)$. The crude oligomers were purified by ionexchange HPLC using a DNAPAC PA200, 4 x 250 mm analytical column (Dionex). Mobile phases A: 25 mM TRIZMA in $\mathrm{H}_{2} \mathrm{O}$, pH 8.0. B: 25 mM TRIZMA, $1.25 \mathrm{M} \mathrm{NaCl}$ in $\mathrm{H}_{2} \mathrm{O}$, pH 8.0. 
or A: $10 \mathrm{mM} \mathrm{NaOH}$ in $\mathrm{H}_{2} \mathrm{O}$, pH 12.0. B: $10 \mathrm{mM} \mathrm{NaOH}, 1.5 \mathrm{M} \mathrm{NaCl}$ in $\mathrm{H}_{2} \mathrm{O}$, pH 12.0, flow $1 \mathrm{ml} / \mathrm{min}$ detection at $260 \mathrm{~nm}$. Purified oligonucleotides were desalted over Sep-Pak cartridges, quantified at $260 \mathrm{~nm}$ using extiction coefficients as determined previously for tricyclonucleosides, ${ }^{31}$ and analyzed by ESI-- mass spectrometry. Oligonucleotides were then stored at $18^{\circ} \mathrm{C}$.

UV-melting curves. Absorbances were monitored at $260 \mathrm{~nm}$ and the heating rate was set to $0.5^{\circ} \mathrm{C} / \mathrm{min}$. A cooling-heating-cooling cycle in the temperature range $20-80^{\circ} \mathrm{C}$ was applied. $T_{\mathrm{m}}$ values were obtained from the derivative curves using the Varian WinUV software. To avoid evaporation of the solution, the sample solutions were covered with a layer of dimethylpolysiloxane. All measurements were carried out in $150 \mathrm{mM} \mathrm{NaCl}, 10 \mathrm{mM} \mathrm{Na}-$ phosphate, $\mathrm{pH} 7.0$ with duplex concentration of $2 \mu \mathrm{M}$.

CD-spectroscopy. CD spectra were recorded using the same buffer conditions and oligonucleotide concentrations as for UV melting curves. All CD spectra were collected at $20^{\circ} \mathrm{C}$ between 210 to $320 \mathrm{~nm}$ at a $50 \mathrm{~nm} / \mathrm{min}$ rate and were baseline-corrected against buffer. The reported spectra correspond to the average of at least three scans.

\section{Acknowledgments}

Financial support by the Swiss National Science Foundation (grant-No.: 200020-130373) and by the Association Monégasques contre les Myopathies (AMM) is gratefully acknowledged. We thank the group of Chemical Crystallography of the University of Bern (PD Dr. P. Macchi) for the X-ray structure solution and the Swiss National Science Foundation (R'equip project 206021_128724) for co-funding the single crystal X-ray diffractometer at the department of Chemistry and Biochemistry of the University of Bern. 


\section{Supporting Information}

Copies of ${ }^{1} \mathrm{H}$-, ${ }^{13} \mathrm{C}$-, ${ }^{19} \mathrm{~F}$-, and ${ }^{31} \mathrm{P}$ - NMR spectra of compounds $\mathbf{2 - 1 8}$ and X-ray structural data (CIF) of compound 16. This information is available free of charge via the Internet at http://pubs.acs.org

\section{References}

(1) Biffinger, J. C.; Kim, H. W.; DiMagno, S. G. ChemBioChem 2004, 5, 622.

(2) Dalvit, C.; Vulpetti, A. ChemMedChem 2011, 6, 104.

(3) Hagmann, W. K. J. Med. Chem. 2008, 51, 4359.

(4) Patra, A.; Paolillo, M.; Charisse, K.; Manoharan, M.; Rozners, E.; Egli, M. Angew. Chem. Int. Ed. 2012, 51, 11863.

(5) Pallan, P. S.; Greene, E. M.; Jicman, P. A.; Pandey, R. K.; Manoharan, M.; Rozners, E.; Egli, M. Nucleic Acids Res. 2011, 39, 3482.

(6) Anzahaee, M. Y.; Watts, J. K.; Alla, N. R.; Nicholson, A. W.; Damha, M. J. J. Am. Chem. Soc. 2011, 133, 728.

(7) Watts, J. K.; Martin-Pintado, N.; Gomez-Pinto, I.; Schwartzentruber, J.; Portella, G.; Orozco, M.; Gonzalez, C.; Damha, M. J. Nucleic Acids Res. 2010, 38, 2498.

(8) Allerson, C. R.; Sioufi, N.; Jarres, R.; Prakash, T. P.; Naik, N.; Berdeja, A.; Wanders, L.; Griffey, R. H.; Swayze, E. E.; Bhat, B. J. Med. Chem. 2005, 48, 901. 
(9) Dowler, T.; Bergeron, D.; Tedeschi, A.-L.; Paquet, L.; Ferrari, N.; Damha, M. J. Nucleic Acids Res. 2006, 34, 1669.

(10) Kalota, A.; Karabon, L.; Swider, C. R.; Viazovkina, E.; Elzagheid, M.; Damha, M. J.; Gewirtz, A. M. Nucleic Acids Res. 2006, 34, 451.

(11) Egli, M.; Pallan, P. S.; Allerson, C. R.; Prakash, T. P.; Berdeja, A.; Yu, J.; Lee, S.; Watt, A.; Gaus, H.; Bhat, B.; Swayze, E. E.; Seth, P. P. J. Am. Chem. Soc. 2011, 133, 16642.

(12) Pallan, P. S.; Yu, J.; Allerson, C. R.; Swayze, E. E.; Seth, P.; Egli, M. Biochemistry 2011, 51, 7.

(13) Seth, P. P.; Yu, J.; Jazayeri, A.; Pallan, P. S.; Allerson, C. R.; Østergaard, M. E.; Liu, F.; Herdewijn, P.; Egli, M.; Swayze, E. E. J. Org. Chem. 2012, 77, 5074.

(14) Seth, P. P.; Pallan, P. S.; Swayze, E. E.; Egli, M. ChemBioChem 2013, 14, 58.

(15) Jung, M. E.; Dwight, T. A.; Vigant, F.; Østergaard, M. E.; Swayze, E. E.; Seth, P. P. Angew. Chem. Int. Ed. 2014, 53, 9893.

(16) Altmann, K. H.; Kesselring, R.; Francotte, E.; Rihs, G. Tetrahedron Lett. 1994, $35,2331$.

(17) Marquez, V. E.; Siddiqui, M. A.; Ezzitouni, A.; Russ, P.; Wang, J.; Wagner, R. W.; Matteucci, M. D. J. Med. Chem. 1996, 39, 3739.

(18) Østergaard, M. E.; Dwight, T.; Berdeja, A.; Swayze, E. E.; Jung, M. E.; Seth, P. P. J. Org. Chem. 2014, 79, 8877.

(19) Østergaard, M. E.; Southwell, A. L.; Kordasiewicz, H.; Watt, A. T.; Skotte, N. H.; Doty, C. N.; Vaid, K.; Villanueva, E. B.; Swayze, E. E.; Frank Bennett, C.; Hayden, M. R.; Seth, P. P. Nucleic Acids Res. 2013, 41, 9634.

(20) Rigo, F.; Hua, Y.; Chun, S. J.; Prakash, T. P.; Krainer, A. R.; Bennett, C. F. Nat. Chem. Biol. 2012, 8, 555. 
(21) Dugovic, B.; Leumann, C. J. J. Org. Chem. 2014, 79, 1271.

(22) Steffens, R.; Leumann, C. Helv. Chim. Acta 1997, 80, 2426.

(23) Lorenz, J. C.; Long, J.; Yang, Z.; Xue, S.; Xie, Y.; Shi, Y. J. Org. Chem. 2003, 69, 327.

(24) Lietard, J.; Leumann, C. J. J. Org. Chem. 2012, 77, 4566.

(25) Luisier, S.; Silhar, P.; Leumann, C. J. Nucleic Acids Symp. Ser. 2008, 581.

(26) Divakar, K. J.; Reese, C. B. J. Chem. Soc. Perkin 1 1982, 1171.

(27) MacMillan, A. M.; Verdine, G. L. J. Org. Chem. 1990, 55, 5931.

(28) Saenger, W. Principles of Nucleic Acid Structure; Springer-Verlag: New York, 1984.

(29) Dugovic, B.; Wagner, M.; Leumann, C. J. Beilstein J. Org. Chem. 2014, 10, 1840.

(30) Ittig, D.; Gerber, A. B.; Leumann, C. J. Nucleic Acids Res. 2011, 39, 373.

(31) Renneberg, D.; Leumann, C. J. J. Am. Chem. Soc. 2002, 124, 5993.

(32) Sowers, L. C.; Shaw, B. R.; Sedwick, W. D. Biochem. Biophys. Res. Commun. 1987, 148,790 .

(33) Steffens, R.; Leumann, C. J. J. Am. Chem. Soc. 1999, 121, 3249. 